Ritrýnd grein birt 31. desember 2020

\title{
Fjarkennsla og stafræn tækni í framhaldsskólum á tímum farsóttar vorið 2020: Sjónarhóll kennara og stjórnenda
}

\author{
Puríður Jóna Jóhannsdóttir og Sólveig Jakobsdóttir \\ Abstract $\quad$ Um höfunda About the authors $\quad$ Heimildir
}

Pegar loka purfti framhaldsskólum á Íslandi vegna heimsfaraldursins COVID-19 á vorönn 2020 var tekin upp fjarkennsla á netinu. Hér er kynnt rannsókn sem snerist um hvernig skólar og kennarar tókust á við pað verkefni og hvaða lærdóm mætti draga af pví til framtíðar. Kennarar og skólastjórnendur ( $\mathrm{N=827)}$ svöruðu spurningakönnun um hvernig skólarnir voru í stakk búnir að takast á við fjarnám, hvaða breytingar urðu á notkun stafrænnar tækni, hvernig háttað var kennslufræðilegum og tæknilegum stuðningi við kennara við pessar breyttu aðstæður og hvernig reynslan af fjarkennslunni gæti haft áhrif á próun kennsluhátta til framtíðar. Niðurstöður benda til að skólar hafi verið fremur vel í stakk búnir að takast á við aukið fjarnám, bæði hvað varðar stafræn verkfæri og aðgengi nemenda að tækni. Í um helmingi skólanna var töluverð reynsla af fjarnámi, tæpur helmingur kennara hafði reynslu af fjarkennslu og taldi pá reynslu hafa gagnast vel. Svör kennara við opnum spurningum $(\mathrm{N}=659)$ leiddu í ljós að helstu áskoranir voru að halda sambandi við nemendur og passa að peir gæfust ekki upp. Álag á kennara jókst pegar peir purftu að sinna kennslu frá heimili sínu par sem vinnuaðstæður voru oft krefjandi. Nefnt var að erfitt hefði verið að beita fjölbreyttum kennsluháttum í fjarkennslunni og að tilhneiging hefði verið til að kennslan færðist í hefðbundið form par sem kennari væri í hlutverki miðlara en nemendur óvirkir hlustendur. Reynslan af kennslu á netinu opnaði augu kennara fyrir tækifærum til að koma betur til móts við parfir einstakra nemenda með nýtingu tækni. Sumir töldu líklegt að skólar myndu í auknum mæli bjóða upp á blandað nám, p.e. nýta bæði fjarnám og staðnám sem gæti orðið til pess að auka sveigjanleika í skólastarfi. Til pess að stuðla að próun náms og kennslu í framtíðinni er brýnt verkefni að efla tæknifærni kennara í tengslum við pekkingu í kennslufræði.

Efnisorð: COVID-19, fjarnám, kennslufræði, tæknipekking kennara, stafræn tækni, framhaldsskólar

\section{Inngangur}

Pegar loka purfti framhaldsskólum vegna heimsfaraldurs COVID-19 vorið 2020 var kennsla í peim greinum sem hægt var færð yfir í fjarnám á neti. Рað átti við um flestar bóklegar greinar en verklegum páttum í verk- og starfsmenntun var stundum frestað pangað til opna mátti skólana að nýju í maí. Petta var mikil áskorun fyrir bæði nemendur og kennara svo og skólastjórnendur en almennt var enginn eða mjög stuttur tími sem gafst til að undirbúa skipulag og kennslu. Til að geta sinnt fjarkennslu á neti purftu kennarar að vera færir um að nota stafræn verkfæri, s.s. ýmis forrit sem notuð voru til að hafa samskipti við nemendur á netinu, undirbúa kennslu, leggja fyrir verkefni og skipuleggja námsmat. Einnig purfti að vera til viðeigandi búnaður til fjarkennslu í skólunum svo og aðgengilegur fyrir kennara heima, par sem peir unnu flestir á meðan skólar voru lokaðir. Pað er pó ekki nóg að kunna á tæknina heldur parf kennslufræðilega pekkingu pegar nám og kennsla, sem 
skipulögð hefur verið fyrir staðnám, er færð yfir í fjarnám á netinu (König, Jäger-Biela og Glutsch, 2020). Рað kallar við venjulegar kringumstæður á ráðgjöf og pjálfun fyrir pá kennara sem enga reynslu hafa af fjarkennslu.

Hvernig voru framhaldsskólakennarar almennt í stakk búnir að takast á við að kenna í fjarnámi á netinu? Vegna pess hversu margir framhaldsskólar á Íslandi hafa boðið fjarnám eða dreifnám undanfarna áratugi er líklegt að nokkuð margir framhaldsskólakennarar hafi reynslu af fjarkennslu. Í framhaldsskólum á Íslandi hefur hugtakið fjarnám verið notað um nám sem hægt er að taka alfarið í fjarnámi án pess að mæta nokkurn tíma í skólann og almennt er um að ræða áfanga í bóknámi. Hugtakið dreifnám hefur hins vegar verið notað um nám sem gerir kröfur um að nemendur mæti í nokkrar staðbundnar lotur í skólann á námstímanum en pess á milli fer nám og kennsla fram á netinu. Verk- og starfsnám er oftar boðið í dreifnámi. Árið 2017 var hægt að stunda fjarnám eða dreifnám við 5 framhaldsskóla á höfuðborgarsvæðinu og 13 skóla á landsbyggðinni (Sólveig Jakobsdóttir og Puríður Jóhannsdóttir, 2018). Í mörgum skólum eru pví kennarar sem hafa reynslu af fjarkennslu sem gæti nýst við pessar óvenjulegu aðstæður en í öðrum skólum hafa kennarar enga slíka reynslu. Markmið peirrar rannsóknar sem hér er kynnt er að afla upplýsinga um hvernig skólar og kennarar tókust á við pað verkefni að færa alla kennslu í fjarnám og hvaða lærdóm megi draga af pví til framtíðar. Leitað verður svara við eftirfarandi rannsóknarspurningum:

1. Hvernig tókst skólinn á við pað verkefni að færa nám og kennslu í fjarnám á vorönn 2020?

- Hvernig voru skólarnir í stakk búnir tæknilega og kennslufræðilega?

- Hvaða breytingar urðu í nýtingu stafrænnar tækni?

- Hverjar voru helstu áskoranir og álitamál fyrir kennara og stjórnendur?

- Hvaða jákvæðu reynslu upplifðu kennarar?

2. Аð hvaða marki telja kennarar að reynslan af breytingunum skipti máli fyrir próun kennsluhátta til framtíðar?

\section{Baksvið}

Á Íslandi hefur verið hægt að stunda framhaldsskólanám í fjarnámi í yfir 20 ár. Fjarnám í bóknámsgreinum hefur í flestum framhaldsskólum verið skipulagt alfarið sem fjarnám á neti par sem nemendur hafa aldrei purft að mæta í skólann nema í lokapróf. Fjarnám í verk- og starfsgreinum hefur verið skipulagt sem fjarnám með mætingu í staðlotur fyrir verklega hluta námsins í einhverjar vikur á önn og kallast pað fyrirkomulag dreifnám.

Árið 2010 var gerð úttekt á fjarnámi í peim premur skólum sem pá höfðu flesta fjarnema, p.e. Fjölbrautaskólanum við Ármúla, Verzlunarskóla Íslands og Verkmenntaskólanum á Akureyri (Sólveig Jakobsdóttir og Purîur Jóhannsdóttir, 2010). Í úttektinni kom fram að á pessum tíma voru fjarnemar í grófum dráttum prír hópar; fullorðið fólk 20-40 ára og eldri sem var að halda áfram námi eftir hlé og var oft komið með fjölskyldu og í vinnu; framhaldsskólanemar sem voru að taka einstaka áfanga til að flýta fyrir sér í námi; og grunnskólanemendur sem voru að taka staka framhaldsskólaáfanga. Fyrir pá sem bjuggu á stöðum par sem ekki var framhaldsskóli var búseta ástæðan fyrir pví að velja pann kost að vera í fjarnámi. Á pessum tíma voru kennsluvefir á netinu almennt nýttir til að setja upp skipulag áfanga og leggja fyrir verkefni. Algengast var að nota umræðupræði með rituðum texta fyrir samskipti kennara og nemenda en lítið var um samvinnu og samskipti nemenda í fjarnáminu. Notkun hljóð- og myndefnis var lítið nýtt pó að dæmi væru um pað. Höfundar úttektar bentu á að tæknin væri vannýtt og mikilvægt væri að próa kennsluhætti sem stuðluðu að samvinnu og samræðum ásamt aðferðum til að efla samkennd og samhjálp nemenda en rannsóknir hafa bent til að slíkt skipti máli varðandi gott gengi í fjarnámi (Purîđur Jóhannsdóttir, 2007). Á síðasta áratug hafa kennsluhættir víða verið í próun með vaxandi nýtingu á nýjum kostum sem bjóðast með stafrænni tækni. Talað mál er í auknum mæli notað í samtímasamskiptum, svo sem netfundir, upptökur/ talglærur til kennslu (vendikennsla) og munnleg verkefnaskil nemenda (dæmi er Menntaskólinn á Tröllaskaga, sjá Puríður Jóhannsdóttir, 2017). 
Nýleg úttekt Sólveigar Jakobsdóttur og Puríðar Jóhannsdóttur (2018) leiddi í ljós að töluverðar breytingar hafa orðið á framboði fjarnáms á framhaldsskólastigi á síðasta áratug. Nýjustu tölur um fjarnám í framhaldsskólum frá Hagstofu Íslands eru frá skólaárinu 2019-2020 (Hagstofa Íslands, 2020) en pá voru skráđir fjarnemar í 17 af 35 framhaldsskólum á Íslandi. Fjölbrautaskólinn við Ármúla var sá skóli sem hafði langflesta fjarnema (719 af $2382 \mathrm{sem}$ er 30\% af heildarfjöldanum). Sjö skólar til viðbótar voru með fleiri en 100 fjarnema, 6 með 11-100 fjarnema en 21 með örfáa eða engan.

Á síðasta áratug varð fjarnám sóknarfæri í skólapróun einkum fyrir skóla á landsbyggðinni en margir peirra hafa skipulagt fjarnám eða dreifnám í verk- og iðngreinum. Árið 2013 var Fjarmenntaskólinn stofnaður sem samvinnuvettvangur 13 skóla á landsbyggðinni með pað að markmiði að nýta fjarnám til að auka og bæta námsframboð. Skólarnir gerðu samkomulag um annars vegar að samnýta bóknámsáfanga pannig að nemendur gætu tekið áfanga sem eru í boði í hinum skólunum í fjarnámi. Með peim hætti nýtist sérhæfing kennara betur og námsframboð getur verið meira en ella. Hins vegar var gert samkomulag um að nokkrir skólar ynnu saman að framkvæmd og skipulagi starfsnáms, til dæmis sjúkraliðanáms og vélstjórnarnáms. Kennslan er skipulögð sem dreifnám par sem bókleg kennsla fer fram á netinu en verkleg kennsla í staðlotum í einhverjum skólanna. Petta nám er í mörgum tilvikum skipulagt í samvinnu við Tækniskólann og Fjölbrautaskólann við Ármúla. Parna hafa möguleikar fjarnáms verið notaðir til að endurskipuleggja nám og kennslu og opnað möguleika fyrir skóla til að vinna saman á annan hátt en áður var unnt.

Pegar framhaldsskólunum var lokað vorið 2020, og breyta purfti kennslu í fjarkennslu, voru netfundir með forritum eins og Zoom og Teams kostur sem margir kennarar völdu. Netfundir hafa pann kost að par virðist hægt að líkja eftir kennslu og samskiptum í venjulegri kennslustofu par sem kennarar geta hitt nemendur sína samtímis pó að peir geti ekki verið á sama stað (Teräs o.fl., 2020). Alpjóðlegar rannsóknir hafa pó bent á ókosti sem fylgja netfundum í rauntíma. Pannig benda Teräs og félagar (2020) á að víða um heim er nettenging nemenda ekki nógu góð til að hægt sé að halda netfundi hnökralaust. Annað vandamál snýr að kennslufræðinni en pað virðist vera tilhneiging til að nota netfundi fyrir íhaldssama kennsluhætti par sem kennsla er í formi fyrirlestra og ekki er gert ráð fyrir pátttöku nemenda. Svo virðist sem pað hversu hratt purfti að færa kennsluna á netið hafi ekki gefið kennurum færi á að aðlaga kennsluhætti að fjarkennslu pannig að margir hafi reynt að yfirfæra hefðbundna nálgun í staðkennslu yfir í fjarnámið. Margir kennarar kunna ef til vill ekki aðrar aðferðir en pess er vænst að reynsla af fjarkennslunni opni augu kennara fyrir hvernig parf að aðlaga nám og kennslu að nýjum miðli. Peir kennarar sem höfðu reynslu af að kenna í fjarnámi fyrir lokun skóla vegna COVID-19 gátu væntanlega nýtt sér pá reynslu en almennt virðast kennarar um allan heim hafa haft frjálsar hendur um hvernig peir útfærðu fjarkennsluna.

Sumir kennarar hafa próað kennsluhætti í staðkennslu með mikilli virkni og pátttöku nemenda og pað getur reynst misauðvelt að laga pá að netkennslu. Rannsókn meðal finnskra kennara (Teräs o.fl., 2020) sýndi að reynslan af að færa kennsluna í fjarnám styrkti fagmennsku peirra og peir mátu tækifæri til að nýta nýja tækni til náms og kennslu út frá peim kennslufræðilegu möguleikum sem tæknin bauð upp á. Finnsku kennararnir sem tóku pátt í pessari rannsókn höfðu áhyggjur af jafnræði til náms og að nemendur með sérparfir, peir sem eiga erfitt með nám eða hafa veikt bakland, myndu dragast enn meira aftur úr eða hætta í námi við pessar aðstæður. Prátt fyrir að kennararnir sæju mikil sóknarfæri í að bæta nám með aukinni nýtingu fjarnámsformsins vöruðu peir við að fjarnám yrði notað til að minnka kennslu og gera ráð fyrir að nemendur gætu stundað sjálfstætt nám á netinu. Í rannsókn meðal pýskra grunnskóla- og framhaldsskólakennara var sjónum annars vegar beint að hvernig kennurum gekk að halda sambandi við nemendur og hins vegar hvernig pættir eins og hæfni í notkun tækni og kennslufræðileg pekking höfðu áhrif á hvernig peim gekk að útfæra kennsluna í fjarnámi (König o.fl., 2020). Markmiðið var að kanna hlutverk upplýsinga- og samskiptatækni í að viðhalda skólahaldi á tímum COVID-19. Niðurstöður sýndu að tæknin var lykilverkfæri við hönnun fjarnáms og hæfni kennara til að nota tækni skipti sköpum í pví verkefni að útfæra fjarkennslu á netinu. 


\section{Framkvæmd}

Í pessari grein er byggt á svörum 823 starfsmanna (724 kennara og 99 stjórnenda) úr framhaldsskólum sem pátt tóku í rannsókn á vegum Menntavísindastofnunar Háskóla Íslands um áhrif COVID-19 faraldursins á nám og kennslu vorið 2020. Í kennarahópnum voru 32 af 724 (4,4\%) sem einnig merktu við að peir væru stjórnendur en ákveðið var að telja pá með í kennarahópnum par sem peir svöruðu sömu spurningum og aðrir kennarar og af svörum margra peirra við opnum spurningum mátti ráða að peir væru fremur að svara spurningalistanum út frá kennslureynslu sinni heldur en stjórnunarreynslu.

Könnunin var send í alla framhaldsskóla landsins og var opin frá 19. maí til 14. júlí. Svör bárust frá 35 skólum. Könnunin var mjög umfangsmikil en pær spurningar úr henni sem hér eru til umfjöllunar voru samdar af sex manna hópi aðila í RANNUM - Rannsóknarstofu í upplýsingatækni og miðlun. ${ }^{1}$ Var um að ræða bæði um tug fjölvalsspurninga og sex opnar spurningar.

Svarhlutfall í fjölvalsspurningum var yfirleitt á bilinu 89-96\% hjá bæði kennurum og stjórnendum en aðeins lægra í nokkrum spurningum hjá stjórnendum (68-85\%). Lýsandi tölfræði var gerð en einnig kí-kvaðrat próf til að skoða mun á svörun stjórnenda og kennara. Pá voru niðurstöður úr spurningu um reynslu kennara af fjarnámi notaðar til að flokka skóla í fimm flokka eftir hlutfalli svarenda úr hópi kennara sem höfðu fjarnámsreynslu.

Í könnuninni var kennurum boðið að svara nokkrum opnum spurningum varðandi hvaða áskoranir voru krefjandi pegar kennslan fluttist í fjarnám, hvort og hvaða jákvæðu reynslu peir upplifðu og hvaða áhrif reynslan myndi hafa á kennsluhætti og skólastarf til framtíðar. Pessar opnu spurningar voru lagðar fyrir til að fá svar við seinni fjórum rannsóknarspurningunum. Rúmur fjórðungur kennara (187 svör) svaraði spurningunni um helstu áskoranir, tæpur fjórðungur (167 svör) svarenda gerði grein fyrir jákvæðri reynslu af pví að færa kennslu í fjarnám á netinu og $17 \%$ pátttakenda (138 svör) svöruðu spurningu um hvaða breytingar peir teldu að gætu orðið á starfsháttum og kennsluháttum í framhaldsskólum í kjölfar fenginnar reynslu af að kennslan færðist á netið.

Svör við opnum spurningum, sem tengjast premur seinni rannsóknarspurningunum, voru fyrst flokkuð gróflega eftir inntaki og í annarri umferð voru flokkarnir settir saman eftir pví hvernig peir tengdust helstu páttum í starfi kennara. Petta er í samræmi við viðurkennda nálgun í greiningu eigindlegra gagna par sem stuðst er fyrst við inntaksgreiningu og síðan greiningu út frá kenningalegum hugtökum (Flick, 2006). Pannig urðu til, í svörum við spurningu um helstu áskoranir, yfirflokkar sem drógu fram í fyrsta lagi kennslufræðilega pætti svo sem aðlögun kennsluhátta, verkefna og námsmats í fjarnámi og í öðru lagi pætti sem snerta pann hluta kennarastarfsins sem snýst um samskipti við nemendur, stuðning, hvatningu og umhyggju. Í priðja lagi kom fram flokkur sem snerist um álag og aukna vinnu kennara meðan á lokun skólanna stóð. Pegar búið var að flokka svör við spurningum um jákvæða reynslu annars vegar og breytingar til framtíðar hins vegar kom í ljós að svörin við peim spurningum voru mjög sambærileg par sem jákvæð reynsla t.d. af nýtingu tækni var líkleg til að hafa áhrif á kennsluhætti til framtíðar. Í niðurstöðum er pví gerð grein fyrir jákvæðri reynslu sem í mörgum tilvikum snerist um að kennarar höfðu lært að nota nýja tækni og hugsanleg áhrif sem pað myndi hafa á kennsluhætti til framtíðar.

\section{Niðurstöður}

Hér er fyrst gerð grein fyrir niðurstöðum um hvernig skólinn var í stakk búinn að takast á við aukið fjarnám, hvernig breytingum og stuðningi við starfsfólk var háttað og hvernig kennarar og stjórnendur sáu fyrir sér breytingar pegar til lengri tíma var litið.

Í kjölfarið er í tveimur undirköflum fjallað um niðurstöður úr svörum við opnum spurningum par sem spurt er annars vegar um pætti sem kennurum og stjórnendum fannst krefjandi og hins vegar um jákvæða reynslu af breytingunum og hugsanlegar breytingar í kennsluháttum og starfsháttum skóla til frambúđar.

\footnotetext{
1 Sólveig Jakobsdóttir, Salvör Gissurardóttir, Skúlína Hlíf Kjartansdóttir, Svava Pétursdóttir, Torfi Hjartarson, Puríður Jóna Jóhannsdóttir.
} 


\section{Hvernig var skólinn í stakk búinn að takast á við aukið fjarnám?}

Skólarnir virtust að mörgu leyti vel í stakk búnir að takast á við aukið fjarnám, bæði hvað varðar stafræn verkfæri og aðgengi nemenda að tækni en jafnframt var töluverð reynsla til staðar af fjarnámi pó hún væri mjög mismikil eftir skólum.

Kennarar voru spurðir hvort peir hefðu haft reynslu af að kenna í fjarnámi og/eða dreifnámi áður en skólanum var lokað í samkomubanninu. Tæpur helmingur (46\%) sagðist hafa slíka reynslu. Skoðað var hversu hátt hlutfall kennara frá hverjum skóla hafði fjarkennslureynslu. Í ljós kom að skólar bjuggu mjög misvel varðandi fjarkennslureynslu kennara. Kennarar frá 33 skólum svöruðu pessari spurningu og voru skólar flokkaðir í fimm flokka eftir pví hversu hátt hlutfall svarenda úr hverjum skóla sagðist hafa slíka reynslu. Pær niðurstöður eru sýndar í Töflu 1. Samkvæmt peim virðist um helmingur skólanna (16) hafa verið vel settur varðandi reynslu starfsmanna af fjarkennslu. Í átta skólum var hlutfallið yfir 80\% og í átta til viðbótar á bilinu 61-80\%. Til viðbótar voru sex skólar par sem um helmingur (41-60\%) svarenda hafði fjarkennslureynslu en 11 skólar voru verr settir hvað pessa reynslu varðaði. Í 7 skólum var pó hlutfallið ekki nema 21-40\% en í fjórum skólum 0-20\%. Hafa parf í huga að hlutfall kennara sem svaraði könnuninni var í sumum skólum ekki hátt pannig að skólar gætu vel verið betur eða verr settir en pessar tölur gefa til kynna.

Tafla 1. Skólar $(N=33)$ flokkaðir eftir hlutfalli kennara $(N=653)$ úr hópi svarenda með reynslu af fjarkennslu.

\begin{tabular}{cccccc}
\hline $\begin{array}{c}\text { Flokkur } \\
\text { skóla }\end{array}$ & $\begin{array}{c}\text { Hlutfall kennara með } \\
\text { reynslu af fjarkennslu }\end{array}$ & $\begin{array}{c}\text { Fjöldi skóla } \\
(N=33)\end{array}$ & $\begin{array}{c}\text { Hlutfall } \\
\text { skóla }\end{array}$ & $\begin{array}{c}\text { Fjöldi kennara frá skóla } \\
(\mathrm{N}=653)\end{array}$ & $\begin{array}{c}\text { Hlutfall } \\
\text { svarenda }\end{array}$ \\
\hline 1 & $0-20 \%$ & 4 & $12 \%$ & 96 & $15 \%$ \\
2 & $21-40 \%$ & 7 & $21 \%$ & 157 & $24 \%$ \\
3 & $41-60 \%$ & 6 & $18 \%$ & 244 & $37 \%$ \\
4 & $61-80 \%$ & 8 & $24 \%$ & 104 & $16 \%$ \\
5 & $81-100 \%$ & 8 & $24 \%$ & 52 & $8 \%$ \\
\hline
\end{tabular}

Við nánari skoðun kom í ljós að allir fjórir skólarnir í flokki 1 með minnstu fjarkennslureynsluna voru miðlungsstórir skólar (250-1000 nemendur) á höfuðborgarsvæðinu en allir átta skólarnir í flokki 5 par sem var mest fjarkennslureynsla voru landsbyggðarskólar, flestir (5) fámennir $(<250$ nemendur) en 3 miðlungsstórir. Í fjarkennsluflokkum 2 til 4 var blanda af landsbyggðarskólum og höfuðborgarskólum.

Gera má ráð fyrir að reynsla af fjarkennslu hafi verið mjög mikilvæg fyrir skólana. Kennarar voru spurðir um að hvaða marki fyrri kynni peirra og reynsla af fjarnámi hefði nýst peim í fjarkennslu pegar skólinn var lokaður í samkomubanni (svarhlutfall 87\%). Taldi helmingur að slík reynsla hefði nýst mikið (22\% mjög mikið og 28\% frekar mikið) á meðan 31\% svaraði „Hvorki mikið né lítið“ og 19\% „Lítið“ (8\% „Frekar lítið“ og 11\% „Mjög lítið“).

Skólastjórnendur voru jafnframt spurðir hversu vel eða illa starfslið skólans virtist búið undir að takast á við aukin tölvusamskipti eða fjarkennslu. Um 77\% (76 manns) svöruðu peirri spurningu og voru 40\% sem svöruðu „Mjög vel“ og 54\% „Frekar vel“ á meðan einungis 5\% svöruðu „Hvorki vel né illa“ og $1 \%$ „Frekar illa“). Marktækur munur var á svörum milli stjórnenda í skólum eftir fjarkennsluflokkuninni í Töflu $1(\chi 2(12, \mathrm{~N}=76)=28,38, \mathrm{p}=0,005)$. Mikill meirihluti stjórnenda (71\%) úr skólunum 16 í flokkum 4 og 5 (með yfir 60\% kennara með reynslu af fjarkennslu), svaraði „Mjög vel“ á meðan innan við helmingur stjórnenda hinna skólanna taldi svo vera (15\% stjórnenda skóla í flokki 3, 33\% úr flokki 2 og $22 \%$ úr flokki 1).

Stjórnendur voru spurðir hversu vel eða illa peir töldu skólann búinn stafrænum verkfærum (tækjum og hugbúnaði) til að takast á við aukin tölvusamskipti eða fjarkennslu. Töldu langflestir skólann vel búinn af tækjum og hugbúnaði (um 57\% svöruðu „Mjög vel“ og 31\% „Frekar vel“). Á hinn bóginn 
voru 7\% sem svöruðu „Hvorki vel né illa“ og 5\% „Frekar illa“ en enginn sem taldi skólann mjög illa búinn (svarhlutfall var 76\%). Ekki var marktækur munur eftir fjarkennsluflokkun skóla hvað pá spurningu varðaði.

Pá voru kennarar og stjórnendur beðnir um álit á hvernig aðgengi nemenda að tækni heima fyrir virtist duga til samskipta eða fjarnáms í samkomubanninu. Niðurstöður má sjá á Mynd 1. Marktækur munur var á svörum hópanna $(\chi 2(4, \mathrm{~N}=770)=11,35, \mathrm{p}=0,023)$. Fleiri stjórnendur töldu aðgengið duga vel. Mikill meirihluti beggja hópa taldi pó að aðgengið dygði vel (18\% kennara mjög vel og $56 \%$ frekar vel; $25 \%$ stjórnenda mjög vel og 63\% frekar vel), en fáir töldu pað duga illa (8\% kennara og enginn stjórnandi).

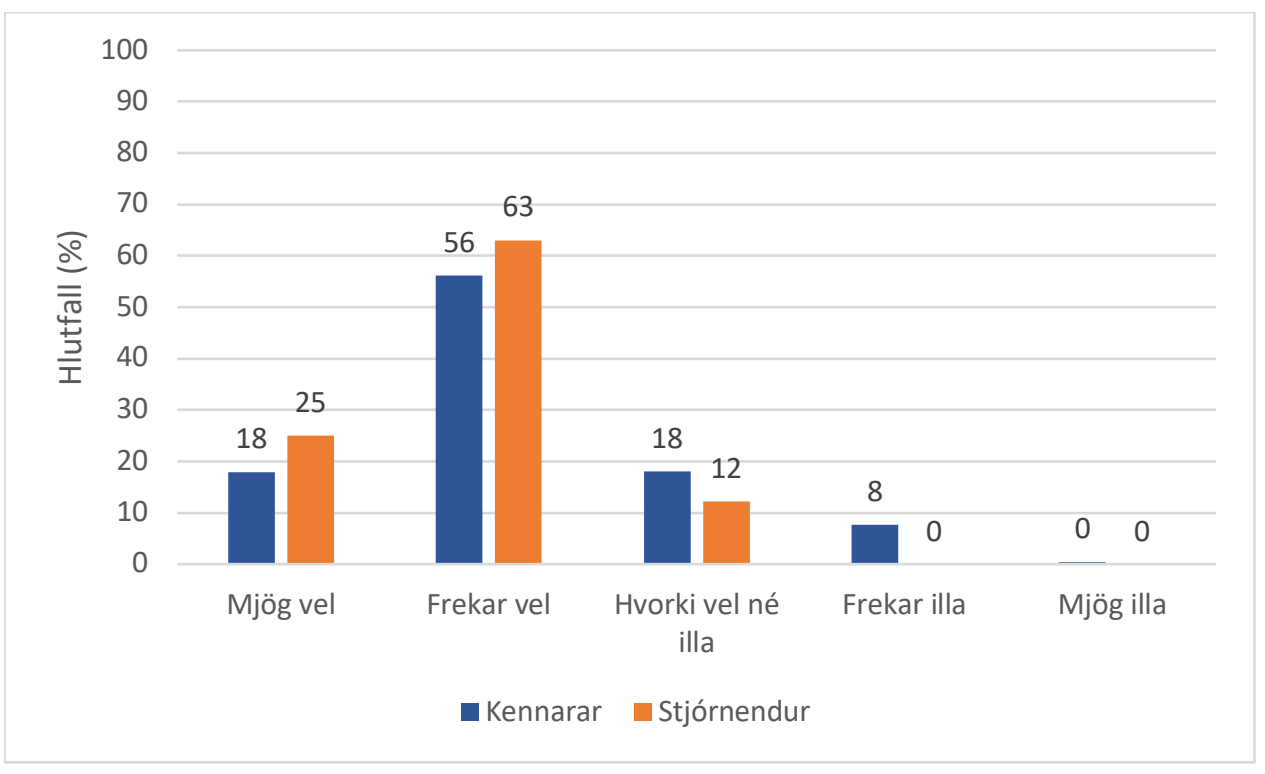

Mynd 1. Svör kennara og stjórnenda við spurningunni: Hvernig virtist aðgengi nemenda að tækni heima fyrir duga til samskipta eða fjarnáms í samkomubanninu?

Marktækur munur var á svörum kennara og skólastjóra eftir skólaflokki (sjá Töflu 1 flokkað frá 1-5 eftir pví hversu hátt hlutfall starfsmanna hafði reynslu af fjarkennslu $(\chi 2(16, \mathrm{~N}=774)=87,54, \mathrm{p}=$ 0,000). Í flokki 5 par sem hæst hlutfall kennara var með reynslu af fjarkennslu (yfir 80\%) taldi $90 \%$ starfsfólks aðgengið duga vel (43\% mjög vel og 47\% frekar vel) en færri töldu pað í hinum skólunum.

\section{Breytingar í nýtingu stafrænnar tækni}

Kennarar og stjórnendur voru spurðir hvort notkun peirra á stafrænni tækni hefði breyst í samkomubanninu. Niðurstöður má sjá á Mynd 2. Ekki var marktækur munur á svörum hópanna. Algengasta svarið var „Töluvert“ (um 44\% svöruðu pví til). Til viðbótar voru $17 \%$ sem töldu um miklar breytingar að ræða (11\% miklar, 6\% mjög miklar). Á hinn bóginn var rúmur priðjungur (34\%) sem taldi um litlar breytingar að ræða og 4\% sögðu breytingar vera engar (svarhlutfall var $94 \%)$. 


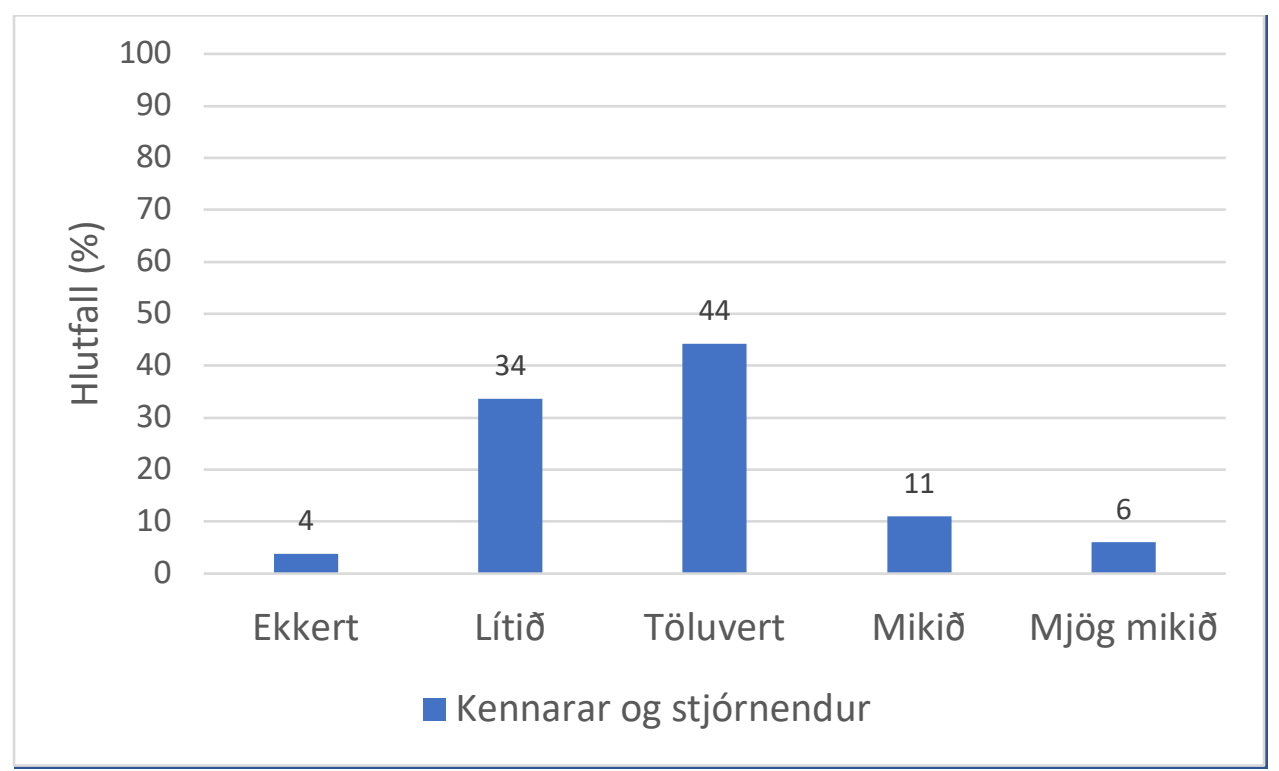

Mynd 2. Svör kennara og stjórnenda við spurningunni: Hefur notkun pín á stafrænni tækni breyst í samkomubanni?

Eitt af pví sem greinilega jókst hjá mörgum voru aukin samskipti við nemendur eftir ýmsum leiðum. Bæði stjórnendur og kennarar voru spurðir: „Нvaða leiðir hefur pú nýtt til að eiga samskipti við nemendur í samkomubanni?"“ Á Mynd 3 sést hlutfall peirra sem svöruðu að peir hefðu notað ýmiss konar stafræn verkfæri „Oftar en áður“ (aðrir svarmöguleikar voru „Eins og áður“; „Sjaldnar en áður“; „Hef aldrei notað“; svarhlutfall var 79-90\%). Mikill meirihluti kennara (87\%) og stjórnenda (74\%) taldi aukningu á netfundakerfum s.s. Zoom eða Teams. Pá voru um 77\% kennara og 52\% stjórnenda sem töldu aukningu á nýtingu tölvupósts sem samskiptaleiðar við nemendur og 51\% kennara og 22\% stjórnenda töldu aukningu á samskiptum í námsumsjónarkerfum/kennslukerfum eins og Moodle eða Innu. Pá var síminn meira nýttur sem samskiptatæki hjá tæplega helmingi kennara og stjórnenda (49 og 37\%). Allmargir (um fjórðungur til rúmlega priðjungur) töldu líka aukningu á nýtingu skráningar- og utanumhaldskerfa á borð við Innu, smáskilaboð og/eða samfélagsmiðla á borð við Facebook, sjá Mynd 3. Marktækur munur var á svörum kennara og stjórnenda í öllum tilvikum. $^{2}$

2 Netfunda- og myndsamtalakerfi: $\chi^{2}(3, \mathrm{~N}=715)=12,9, \mathrm{p}=0,039$; Tölvupóstur: $\chi^{2}(3, \mathrm{~N}=739)=28,21, \mathrm{p}<0,001$; Námsumsjónar- og kennslukerfi: $\chi^{2}(3, \mathrm{~N}=685)=21,66, \mathrm{p}<0,001$; Talsími: $\chi^{2}(3, \mathrm{~N}=667)=27,8, \mathrm{p}<0,001$; Skráningar- og utanumhaldskerfi: $\chi^{2}(3, \mathrm{~N}=710)=14,36, \mathrm{p}=0,002$; Smáskilaboð: $\chi^{2}(3, \mathrm{~N}=653)=25,75, \mathrm{p}<0,001$; Samfélagsmiðlar: $\chi^{2}(3, \mathrm{~N}=657)=10,07, \mathrm{p}=0,018$. 
Netfunda- og myndsamtalakerfi á borđ við Zoom eða Teams, Discord, Google Meet, Skype

Tölvupóst

Námsumsjónar- og kennslukerfi á borð við

Moodle eđa Innu
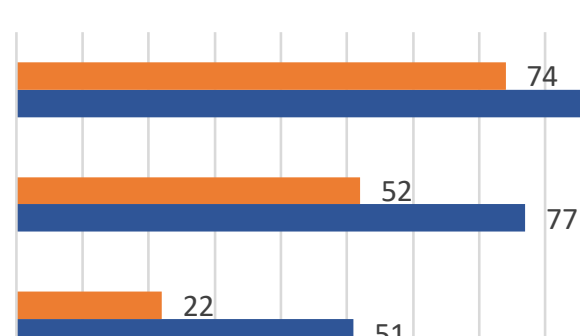

Skráningar- og utanumhaldskerfi á borđ viđ Innu

Smáskilaboð (SMS)

Samfélagsmiðla á borð við Facebook, Messenger, Snapchat, TikTok, Instagram eđa...

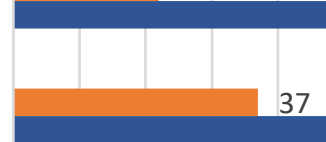

51

Talsíma
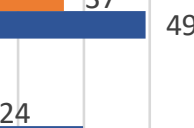

40

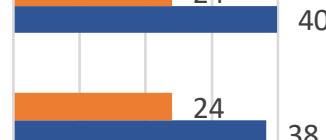

77
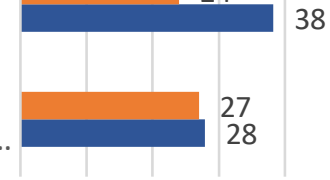

27
28

\section{8}

$\begin{array}{lllllllllll}0 & 10 & 20 & 30 & 40 & 50 & 60 & 70 & 80 & 90 & 100\end{array}$

Hlutfall (\%)

\section{- Stjórnendur Kennarar}

Mynd 3. Hlutfall kennara og stjórnenda sem svarar „Oftar en áður“ við spurningunni: Hvaða leiðir hefur pú nýtt til að eiga samskipti við nemendur í samkomubanni?

Kennarar voru einnig spurðir um að hversu miklu eða litlu leyti peir réðu sjálfir vali á forritum og tækni í samkomubanninu eða hvort um samræmdar aðgerðir hefði verið að ræða af hálfu skólans. Svörin sjást á Mynd 4 (svarhlutfall var 95\%).

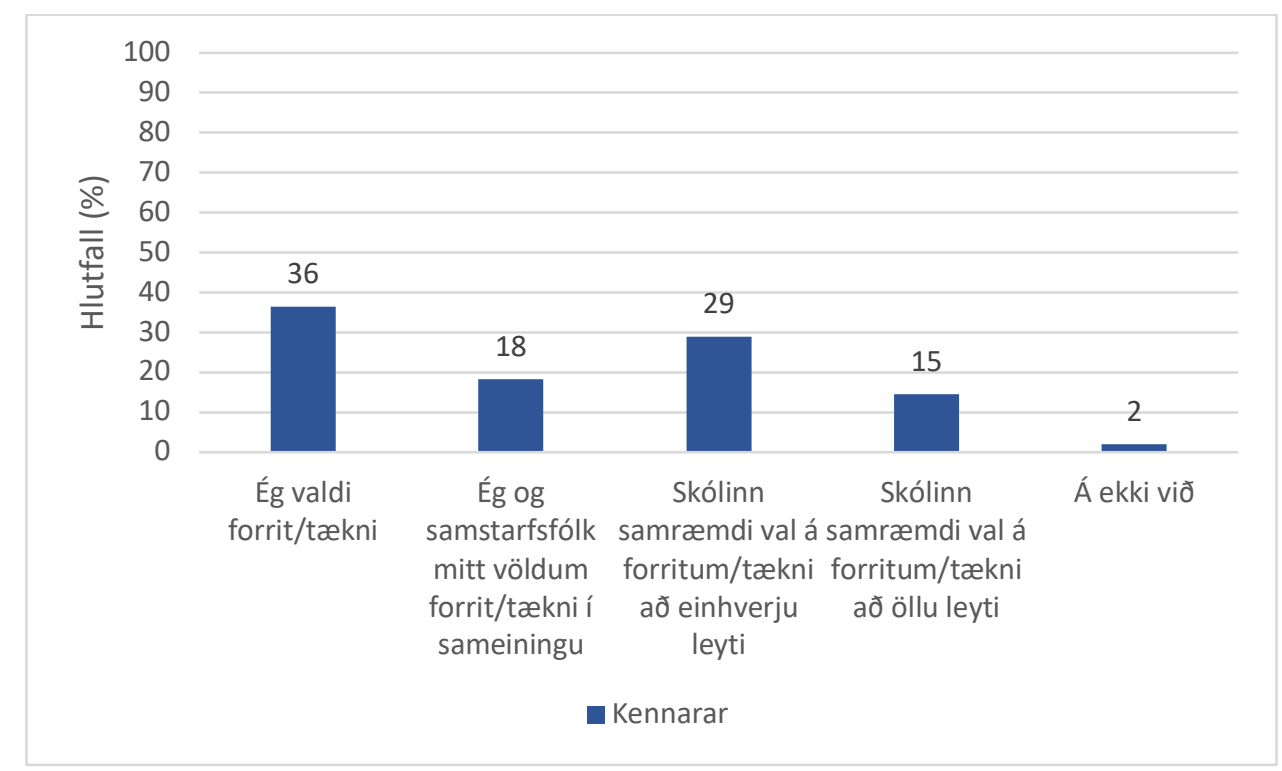

Mynd 4. Svör kennara við spurningunni: Að hvað miklu eða litlu leyti réðir pú sjálf(ur) vali á forritum og tækni á meðan lokað var vegna samkomubanns frekar en að um samræmdar aðgerðir væri að ræða af hálfu skólans? 
Í ljós kom að stór hluti kennara taldi sig hafa haft frjálsar hendur varðandi val á forritum, rúmur priðjungur (36\%) sagðist hafa valið forrit/tækni sjálf og $18 \%$ að starfsfólk hefði gert pað í sameiningu á meðan um $29 \%$ sögðu að samræmdar aðgerðir hefðu verið af hálfu skólans eða að skólinn hefði samræmt valið að öllu leyti (15\%).

\section{Stuðningur}

Kennarar og stjórnendur voru spurðir hverjir í starfsliði skólans hefðu gegnt lykilhlutverki við að leiðbeina um notkun tækni á meðan skólinn var lokaður í samkomubanni. Svör má sjá á Mynd 5. Par kemur fram að algengast var að fólk nefndi starfsfólk í tölvupjónustu (52\% kennara og 66\% stjórnenda) en mjög algengt var einnig að samkennarar væru taldir gegna lykilhlutverki (46\% kennara og 50\% stjórnenda). Pá voru 41\% stjórnenda og 22\% kennara sem nefndu skólameistara eða aðstoðarskólameistara og 21\% stjórnenda og 18\% kennara nefndu aðra stjórnendur. Fátítt var að aðrir væru nefndir en pó voru nokkrir sem merktu við starfsmenn á skólasafni (3\% beggja hópa), námsog starfsráðgjafa ( $2 \%$ kennara, $7 \%$ stjórnenda) eða aðra (9\% kennara, 5\% stjórnenda). Pá voru 8\% kennara en enginn stjórnandi sem töldu engan innan skólans hafa gegnt slíku hlutverki. Marktækur munur var á svörum kennara og stjórnenda varðandi (aðstoðar)skólameistara, aðra stjórnendur, fólk í tölvupjónustu og náms- og starfsráðgjafa par sem hærra hlutfall stjórnenda valdi pá möguleika, en hærra hlutfall kennara en stjórnenda valdi möguleikann „Á ekki við....”3

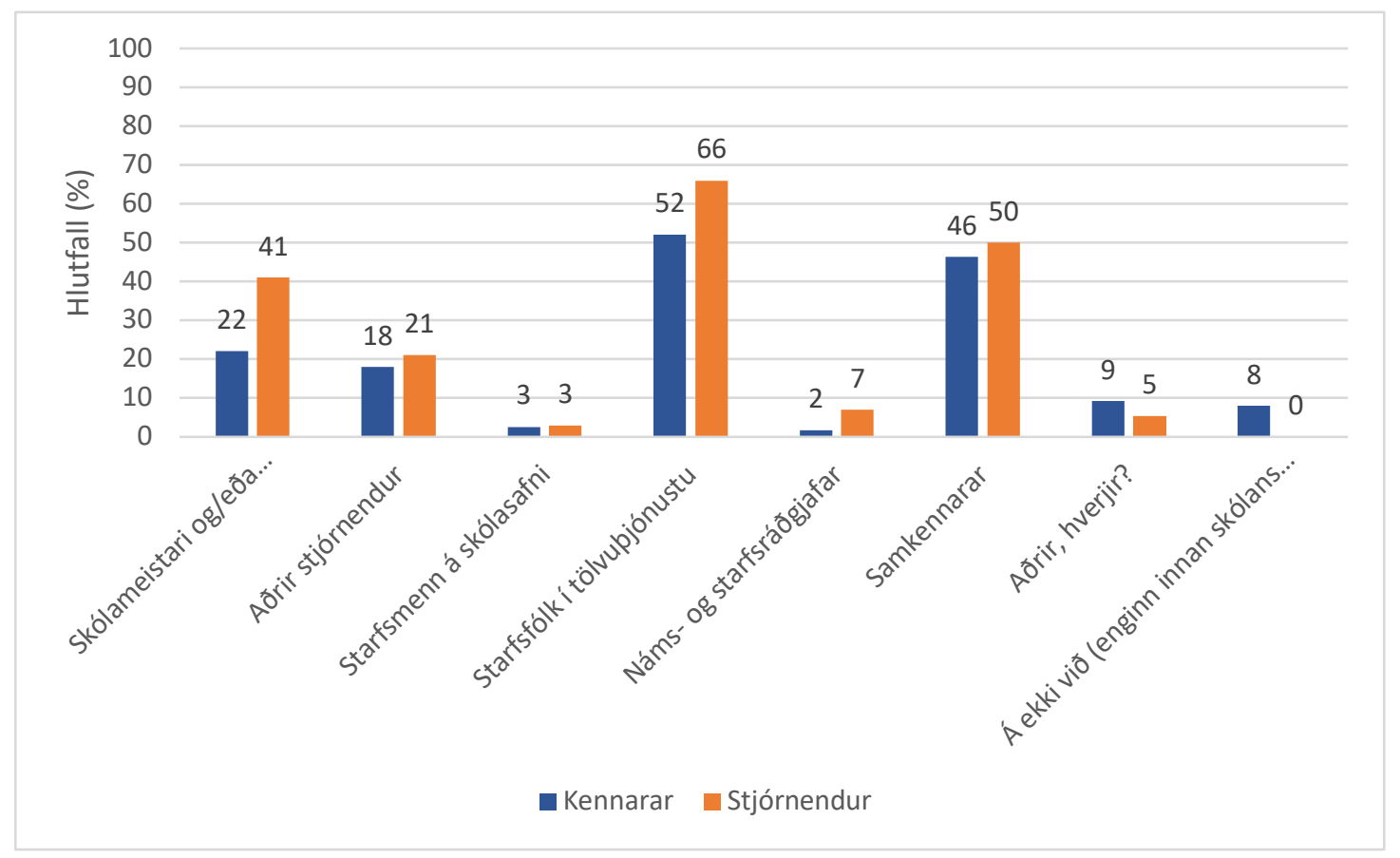

Mynd 5. Svör kennara og stjórnenda við spurningunni: Hverjir í starfsliði skólans hafa gegnt lykilhlutverki við að leiðbeina um notkun tækni á meðan skólinn var lokaður í samkomubanni?

Kennarar og stjórnendur voru spurðir hverjar af peim leiðum sem peir kynnu að hafa farið til að leita pekkingar og stuðnings um notkun tækni í faraldrinum hefðu nýst peim best. Svör má sjá á Mynd 6. Marktækur munur var á svörum kennara og stjórnenda $(\chi 2(5, \mathrm{~N}=762)=43,22, \mathrm{p}<0,001)$.

Skólameistari og/eða aðstoðarskólameistari: $\chi^{2}(1, \mathrm{~N}=823)=18,55, \mathrm{p}<0,001$; Aðrir stjórnendur: $\chi^{2}(1, \mathrm{~N}=823)=15,46, \mathrm{p}<0,001$; Starfsfólk í tölvupjónustu: $\chi^{2}(1, \mathrm{~N}=823)=6,46, \mathrm{p}=0,011$; Náms- og starfsráðgjafar: $\chi^{2}(1, \mathrm{~N}=823)=10,22, \mathrm{p}=0,001$; Á ekki við (enginn innan skólans...): $\chi^{2}(1$, $\mathrm{N}=823)=9,01, \mathrm{p}=0,003$. 


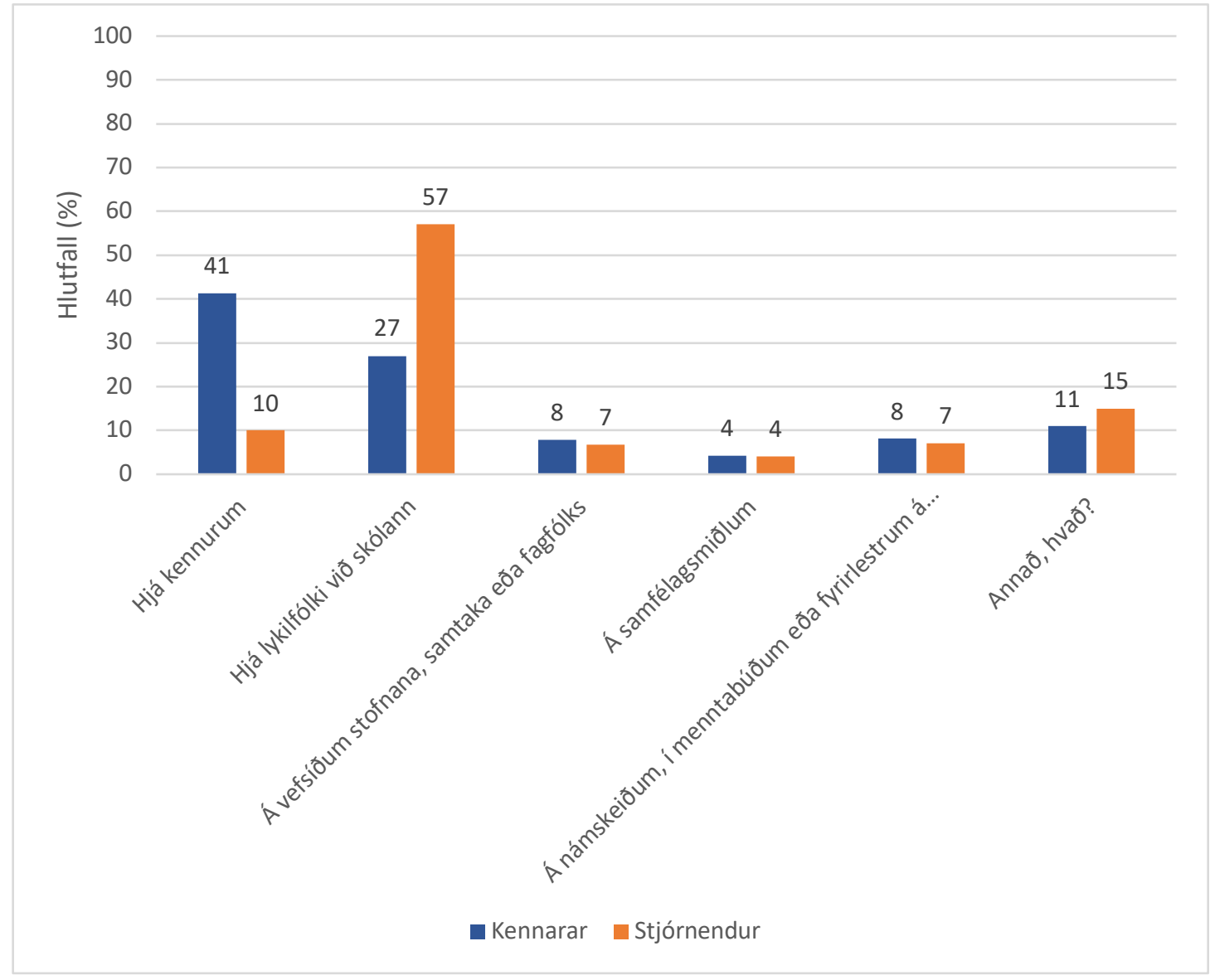

Mynd 6. Svör kennara og stjórnenda við spurningunni: Hverjar af peim leiðum sem pú kannt að hafa farið til að leita pekkingar og stuðnings um notkun tækni í faraldrinum hafa nýst pér best?

Eins og sjá má pá töldu kennarar að best hefði nýst peim að leita til annarra kennara. Um 41\% nefndi pann kost og 27\% hjá lykilfólki við skólann á meðan eingöngu $10 \%$ stjórnenda töldu best að leita til kennara en $57 \%$ til lykilfólks við skólann. Nokkrir merktu svo við vefsíður stofnana, samtaka eða fagfólks (7-8\%). Um 7-8\% merktu við námskeið, menntabúðir eða fyrirlestra; um 4\% við samfélagsmiðla og $11-15 \%$ við annað.

Spurt var hver reynslan væri af tæknilegum stuðningi við starfsfólk. Svör má sjá á Mynd 7. 


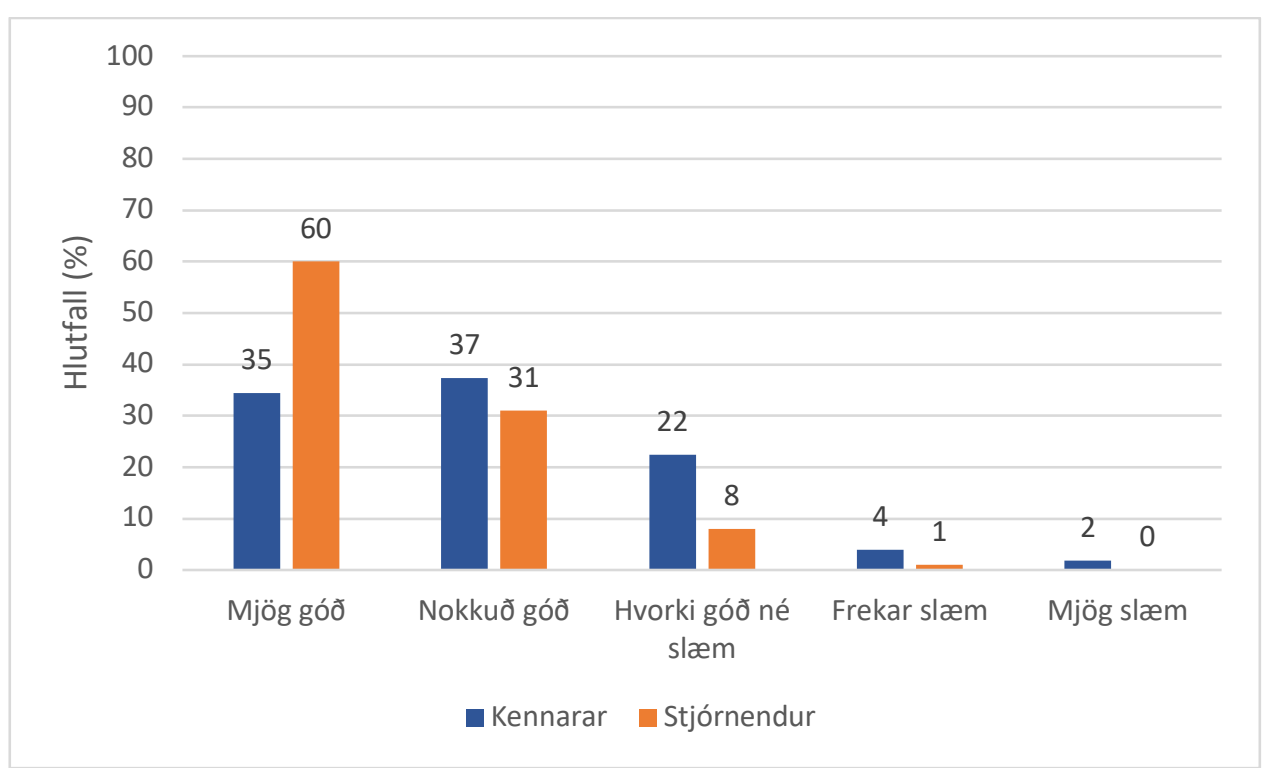

Mynd 7. Svör kennara og stjórnenda við spurningunni: Á meðan lokað var vegna samkomubanns, hver var reynsla pín af tæknilegum stuðningi við starfsfólk?

Par kemur fram að flestir töldu hana mjög eða nokkuð góða (35\% kennara og 60\% stjórnenda töldu hana mjög góða og 31-37\% nokkuð góða) á meðan mun færri töldu hana hvorki góða né slæma (22\% kennara og $8 \%$ stjórnenda) og nokkrir frekar slæma (4\% kennara og 1\% stjórnenda) eða mjög slæma ( $2 \%$ kennara). Marktækur munur var á svörum kennara og stjórnenda $(\chi 2(4, \mathrm{~N}=755)=$ $23,35, \mathrm{p}<0,001)$. Hærra hlutfall stjórnenda en kennara taldi tæknilegan stuðning hafa verið mjög eða nokkuð góðan í sínum svörum.

Stjórnendur svöruðu spurningu um hvort kennarar hefðu fengið kennslufræðilegan stuðning pegar peir fluttu kennsluna yfir í fjarnám í samkomubanni (svarhlutfall 78\%). Um 26\% svarenda töldu að peir hefðu fengið mikinn stuðning, 58\% nokkurn, 8\% lítinn eða engan og 8\% svöruðu „Veit ekki“. Svör kennara við sambærilegri spurningu um hvort peir hefðu fengið lítinn eða mikinn kennslufræðilegan stuðning voru nokkuð á annan veg (svarhlutfall 89\%). Um 17\% töldu að um frekar mikinn (14\%) eða mjög mikinn (3\%) stuðning hefði verið að ræða á meðan 40\% töldu hann hvorki lítinn né mikinn, 20\% frekar lítinn og 22\% mjög lítinn.

\section{Áhrif á kennsluhætti}

Kennarar og stjórnendur voru spurðir „Hversu mikil eða lítil áhrif finnst pér breytingar vegna lokunar skólans í samkomubanni hafa haft á kennsluhætti?" (svarhlutfall 89\%). Marktækur munur var á svörum kennara og stjórnenda $(\chi 2(4, \mathrm{~N}=730)=11,95, \mathrm{p}=0,018)$. Langflestir í báðum hópum töldu pó að um mikil eða töluverð áhrif væri að ræða. Eins og sést á Mynd 8 voru 27\% kennara sem töldu að um mjög mikil áhrif væri að ræða og $24 \%$ mikil en sambærilegar tölur hjá stjórnendum voru $11 \% \operatorname{og} 35 \%$. Til viðbótar voru 39\% beggja hópa sem svöruðu töluverð áhrif. Eingöngu 10\% kennara og $14 \%$ stjórnenda töldu áhrifin lítil eða engin. 


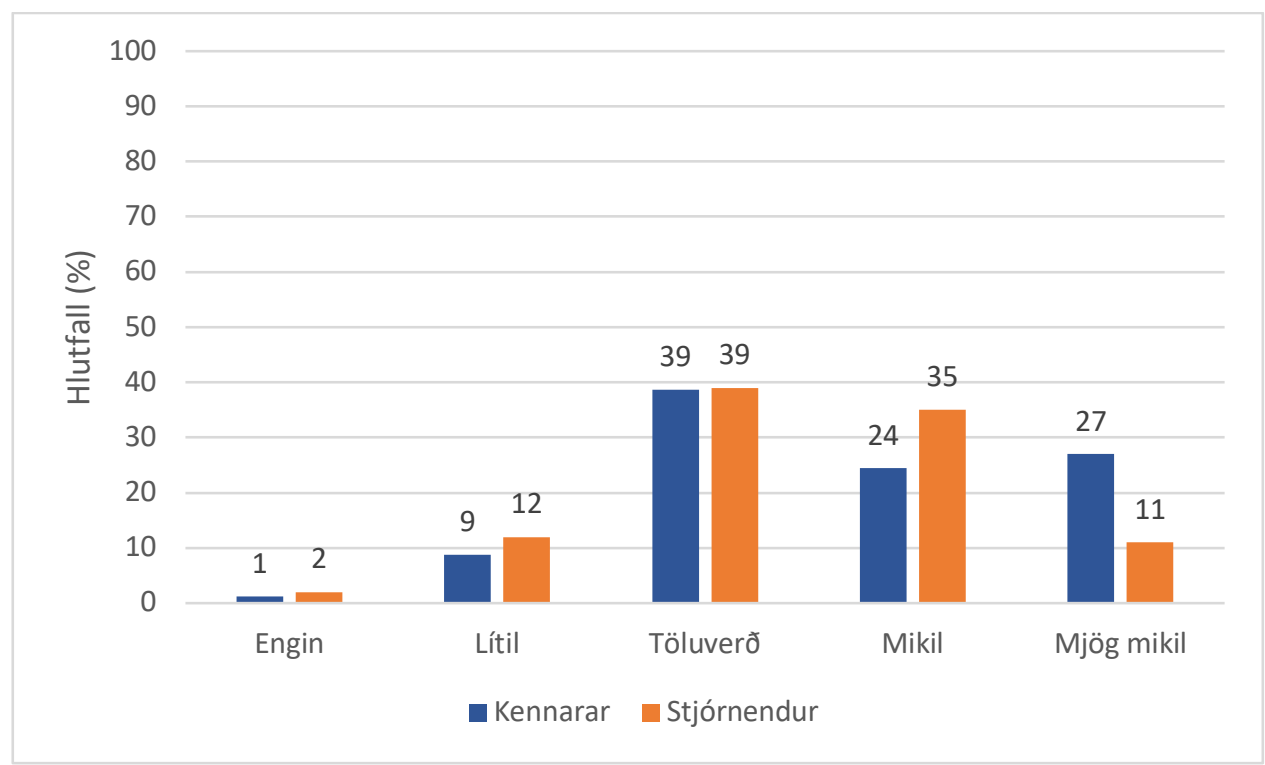

Mynd 8. Svör kennara og stjórnenda við spurningunni: Hversu mikil eða lítil áhrif finnst pér breytingar vegna lokunar skólans í samkomubanni hafa haft á kennsluhætti?

\section{Áskoranir pegar kennsla færðist í fjarnám á netinu}

Í pessum kafla verður gerð grein fyrir svörum við opnum spurningum sem snerust um áskoranir í starfi kennara. Flest svaranna (70 svör) sneru að pví að mesta áskorunin hefði verið að halda sambandi við nemendur, hvetja pá til að sinna náminu og passa að peir gæfust ekki upp og hættu í skólanum. Petta er sú hlið kennarastarfsins sem snýst um hvatningu og ábyrgð kennara á velferð nemenda sinna. Hér er fyrst gerð grein fyrir pví sem kennurum fannst krefjandi varðandi pessar áskoranir og í framhaldi er rætt um kennslufræðilegar áskoranir. Um fjórðungur svara (47 svör) við spurningunni um áskoranir snerust um aukna vinnu, álag kennara og aðstæður heima. Niðurstöður eru kynntar í lok kaflans.

\section{Að halda sambandi við nemendur og hvetja pá i náminu}

Kennurum fannst mikilvægt að halda nemendum virkum en fannst mjög krefjandi að ná til peirra, halda peim í námi og koma í veg fyrir brottfall. Fram kom að oft purfti mikið utanumhald og áminningar til að passa að peir skiluðu verkefnum. Kennarar lögðu áherslu á að mikilvægt hefði verið að hvetja nemendur til dáða, virkja pá til vinnu og svara fyrirspurnum peirra um leið og pær bárust. Fyrir marga nemendur reyndist erfitt að halda rútínu sem lýsti sér í að margir voru helst virkir seinni part dags og á kvöldin. Petta pýddi að vinnudagur kennara „var par af leiðandi stundum fram að miðnætti við að svara nemendum“. Рað var mikið verk að finna pá nemendur sem voru óvirkir og eiga við pá sem gáfust upp. Mörgum leið illa, og kvíði og punglyndi gerði vart við sig. Nemendur áttu erfitt með að koma sér að verki og pá vantaði utanumhaldið sem stundaskráin veitti. Sumir nemendur vildu ekki láta kennara ná til sín og pað gat verið erfitt að ná í pá sem vildu ekki svara skilaboðum, símtali eða tölvupósti. Petta olli kennurum miklum áhyggjum og pó að námsráðgjafar hefðu einnig aðstoðað, hefði pað tekist misvel. Pannig hefði ekki alltaf tekist að koma í veg fyrir að nemar sem stóðu höllum fæti dyttu út:

Pað var erfitt að hafa yfirsýn yfir vinnu nemenda, og auðvelt að missa sjónar á nemendum sem lítið hafa sig í frammi venjulega. Pau áttu auðvelt með að „verða ósýnileg“, og tjáðu sig enn minna en áður, par sem lítið er um augliti til auglitis tengsl í fjarnámi. Nemendur sem eru iðnir við að tjá sig urðu meira áberandi og yfirgnæfðu, hinir hurfu. 
Upplýsingamiðlun til nemenda var krefjandi par sem nemendur fylgdust misvel með og voru misvel læsir á upplýsingar. Tímasetningar á verkefnum og prófum komust oft illa til skila prátt fyrir að upplýsingar væru til staðar:

Ég hringdi oft í nemendur sem ekkert hafði heyrst í og oft voru peir alls ekki með á nótunum, höfu ekki lesið tölvupóst, ekki farið á Innu heldur verið bara heima að bíða eftir einhverju.

\section{Viðkvemir hópar nemenda}

Pað var kennurum mikil áskorun að leita leiða til pess að nálgast nemendur í erfiðri stöðu. Dæmi um einstaklinga í slíkri stöðu voru nemendur á starfsbrautum fyrir fólk með proskahömlun, nemendur af erlendum uppruna og nemendur sem búa við erfiðar aðstæður á heimili. Einnig var nefnt að „nýnemar, sérstaklega drengir voru viðkvæmur hópur og erfitt að ná til peirra“. Pá var hópur nemenda sem átti í vandræðum „bæði námslega og líka andlega“. Sá nemendahópur „klofnaði meira en áður“ og pessir viðkvæmu nemendur hættu, peir „fengu ekki nægan stuðning“:

Sumir nemendur fóru inn í skel - sinntu engu, svöruðu hvorki símtölum né tölvupósti. Erfitt að sætta sig við pað og streita sem fylgdi pví að hugsa til peirra - af hverju eru pau ekki að svara? Er eitthvað alvarlegt í gangi á heimilinu sem gerir pað að verkum að pau geta ekki sinnt pessu?

Fram kom að pað hefði verið sérstaklega mikil áskorun að sinna fötlunum nemendum við pessar aðstæður:

Nærógjörningur aðhalda uppi kennslu fyrir mjög fatlaða nemendur sem purfa manninn með sér. Erfitt að halda vel utan um alla hina fötluðu nemendurna sem gátu fengið heimaverkefni. Erfitt, en gaman, að finna endalaust upp á verkefnum sem nemendur með fötlun geta unnið án aðstoðar. Mismunandi bakland og aðstaða heima hjá peim.

Hvað varðar nemendur af erlendum uppruna var mikilvægt að koma öllum upplýsingum eins skýrt til skila og mögulegt var en mörgum fannst pað ekki ganga vel. Einn kennarinn sagði: „Mér fannst ég ekki ná eins vel til peirra, prátt fyrir að bjóða oft upp á stutta einkatíma.“

Nefnt var að erfitt hefði verið „að halda í pá hugsjón að menntun sé jöfnunartæki ... pegar staða nemenda er ólík heima við“. Tæknibúnaður var misgóður og ekki höfðu allir nemendur jafnan aðgang að tölvu. Pá purftu kennarar stundum að huga að pví „,að nemendur væru með réttu græjurnar heima hjá sér til pess að geta stundað fjarnám“:

Stundum var ekki hægt að halda sig við að kenna samkvæmt stundaskrá í gegnum fjarfundabúnað par sem aðstöðumunur nemenda var töluverður og pau áttu ekki öll hægt með að komast í tæki á ákveðnum tíma.

\section{Kennslufraðilegar áskoranir}

Sumir kennarar töluðu um að peir hefðu reynt að viðhalda kennslu með sama hætti og áður, halda fjölbreytni í kennsluháttum og námsmati og halda uppi gæðum í skólastarfi. Kennarar lýstu hvernig peir purftu að aðlaga námsefni, verkefni og námsmat að kennslu á netinu. Kennarar gerðu kennslumyndbönd, settu upptökur af kennslunni á netið með pví að gera talglærur og aðlöguðu verkefni að netnámi, t.d. með að nýta sér tækni til prófa- og verkefnagerðar og búa til spurningabanka á rafrænu formi. Einhverjir höfðu notað munnlega endurgjöf sem tekin var upp og skilað til nemenda. Nemendur lærðu líka að skila af sér verkefnum á fjölbreyttara formi en áður og margir töldu pað verða nýtt áfram. Sumir nýttu samvinnusvæði s.s. Google Docs á netinu til að veita sérstaka aðstoð. Pá purftu kennarar að finna nýjar útfærslur af verkefnum sem höfðu verið skipulögð sem samvinnuverkefni í kennslustundum í staðnámi. Mikil áskorun fólst í að gera verkefnin eins lifandi og pau gætu verið í kennslustofu: 
Par sem tungumálakennsla byggist á tjáningu að miklu leyti og stöðugri æfingu í henni skriflega, munnlega, með hlustun par sem skilningur er hafður að leiðarljósi, fólst mesta áskorunin í pví að finna og/eða búa til verkefni sem áđur voru oft hópaverkefni í tíma, skrifleg sem og munnleg tjáning í tíma sem allir tóku pátt í á sama tíma og öll saman.

Oft var hópverkefnum breytt í einstaklingsverkefni og mörgum fannst að kennsluhættir yrðu einhæfari og meira gamaldags í fjarnáminu:

Yfir pað heila urðu verkefni „purrari“ og bæði ég og nemendur söknum dýnamíkurinnar sem á sér stað í kennslustofunni. Margt í valdajafnvægi og hlutverkum í skólastofunni varð gamaldags prátt fyrir að reynt hafi verið að gera verkefni fjölbreytt - pá varð petta samt pannig að kennari lagði fyrir og tók svo bara við lausnunum kláruðum frá nemendum.

Á hinn bóginn nefndu sumir að verkefni hefðu verið fjölbreyttari og nemendum verið boðið að velja hvort peir vildu vinna sjálfstætt eða í hóp í fjarnáminu. Flestir kennarar (sjá Mynd 3) héldu kennslustundir á netfundum (Teams, Zoom eða kennslukerfum s.s. Innu, Moodle eða Canvas) en mörgum fannst krefjandi að halda góðum samskiptum við nemendur við pær aðstæður. Sumum fannst að fjölbreyttar kennsluaðferðir hefðu ekki gengið upp í fjarkennslunni:

Kennslan fór aftur til fortíðar par sem pau sátu og hlustuðu á mig tala og ég var heppin ef umræðutímarnir virkuðu. Рað varð enn erfiðara að fá nemendur til pess að tjá sig.

Kennurum fannst erfitt að geta ekki leiðbeint nemendum á sama hátt og í kennslustofu. Ekki mættu allir nemendur á Teams-fundi og peir sem gerðu pað vildu stundum ekki láta sjá sig í mynd. Pað var minna um umræður í netkennslunni, nemendur voru feimnari við að tjá sig en í venjulegri kennslustund. Svo gátu nemendur yfirgefið tíma á netfundi án pess að kennarar tækju eftir pví. Aðrir lýstu góðri reynslu af netkennslunni prátt fyrir allt:

Раð að hafa nemendur í beinum samskiptum og í sama rými er einn af lykilpáttum starfsins. Pessi fjarkennsla nær engan veginn sömu tengingu og áður. Hins vegar, við pessar fordæmalausu aðstæður, pá var petta pað besta sem hægt var að gera í stöðunni og Teamsfundir með bekknum par sem hægt var að tala saman í mynd er ómetanlegt við svona aðstæður. Nemendur eiga hrós skilið fyrir pátttöku og jákvæðni. Fyrirfram var ég ekki viss um að peir myndu mæta svona vel á sama tíma og áður í stundaskrá. Peir eiga allt hrós skilið.

\section{Aukin vinna kennara}

Mörg svör kennara snerust um aukið vinnuálag og greinilegt að pær breytingar sem kennarar purftu að gera á kennslu og námsmati höfðu í för með sér mikla og aukna vinnu. Kennarar sögðu að samskipti við nemendur og utanumhald hefðu tekið mikinn tíma og orku en einnig aðlögun að notkun nýrrar tækni við kennsluna:

Vinnuálag jókst gríðarlega, suma dagana vann ég í 12 klukkustundir og jafnvel meira. Álagið var vegna pess að nú var undirbúningur fyrir tímana mína allt annar en áður, jafnaðist á við fyrsta ár í kennslu pegar maður átti ekkert efni og purfti að búa allt til, purfti að læra á ný tól, verkefnayfirferð jókst og samskipti við nemendur voru með öðrum hætti.

Pegar hópverkefnum var breytt í einstaklingsverkefni fjölgaði peim verkefnum sem kennarar purftu að fara yfir og mikil vinna fór í að ná til nemenda. Nemendur gátu purft einstaklingsaðstoð vegna aðstæðna heima og stundum hjálp vegna tæknivandræða sem tóku mikinn tíma og orku. Pá var aukið álag við að kenna nemendum ný vinnubrögð, eins og að senda skjöl á réttu formi, stundum áttu nemendur erfitt með að skilja fyrirmæli og kenna purfti nemendum á samskipti á netinu, að lesa fyrirmæli til enda og fara eftir peim. Einnig purfti að vera nemendum sem ekki gátu verið í tíma samkvæmt stundatöflu innan handar. Petta skýrðist gjarnan af páttum eins og „stórt heimili, enginn friður, bara ein vél á heimili og einhver annar að taka próf“. Netsamskiptin reyndust tímafrek, bæði 
samskipti við nemendur og samstarfsfólk. „Upplýsingar skila sér sîður pegar tölvupóstum rignir yfir nemendur og aðstandendur og fyrir vikið parf kennari oft að svara óparfa spurningum,...“

Sumir nefndu að pað hefði verið líkamlega erfitt að vinna svona mikið við tölvu. Einnig reyndist krefjandi fyrir kennara að aðskilja vinnu og einkalíf. Nokkrir kennarar (20 svör) nefndu að pað hefði verið áskorun að sampætta heimilislíf og vinnu og að mikið álag hefði verið að sampætta heimaveru barna og kennslu, að fá næði til að sinna vinnunni og að útbúa vinnuaðstöðu við hæfi:

Ég var allan sólarhringinn í vinnunni, hef ekki tekið mér helgarfrí síðan fyrir samkomubann ásamt pví að ég hef unnið langt fram á kvöld mestan hluta tímans.

Miklu meiri tími fór í einfalda hluti pegar sífellt urðu truflanir heima og aðstæður heima höfðu pá áhrif á vinnutímann:

Vinnutíminn hjá mér var frá 21-02 par sem ég var heima með börn á hverjum degi (leikskólastelpurnar fengu annan hvern dag í leikskólanum og skólastelpan annan hvern dag á móti hinum). Maðurinn minn var skikkaður til að mæta í vinnu á hverjum degi. Auk pess átti ég að halda utan um aukið heimanám skólastelpunnar, tónlistarnámið og heimavinnu í tónfræði.

Рað hafði líka áhrif á vinnutíma kennara að nemendur purftu oft hjálp utan venjulegs skólatíma par sem peir voru oft virkastir á kvöldin og á nóttunni. Tölvupóstar og skilaboð biðu kennara á morgnana frá nemendum sem voru búnir að snúa sólarhringnum við. „Álagið hefur verið gríðarlegt en að sama skapi er ég stolt af nemendum mínum fyrir að hafa komist að mestu klakklaust út úr pessu."

\section{Reynsla kennara af að færa kennslu í fjarnám og breytingar til framtíðar}

Hér er gerð grein fyrir niðurstöðum úr svörum um jákvæða reynslu kennara pegar kennslan færðist í fjarnám og hvaða breytingar peir sáu fyrir sér að gætu orðið til frambúðar í ljósi reynslunnar. Langflest svör varðandi jákvæða reynslu, eða 70 svör falla í flokkinn „Læra á ný forrit sem munu nýtast í framtíðinni“ og flest svör um breytingar til framtíðar (42) falla í flokkinn „Aukið hlutfall netkennslu - meiri blanda af stað og fjar“ og næstum jafn mörg svör (36) falla í flokkinn „Aukin nýting tækni í námi og kennslu“.

\section{Ný forrit geta aukið sveigjanleika og fjölbreytni i kennsluháttum og námsmati}

Margir kennarar sögðust hafa lært á ný forrit, töldu að pau myndu nýtast áfram til að auka sveigjanleika og fjölbreytni í kennsluháttum og sáu fyrir sér aukna notkun á starfrænum miðlum til pekkingaröflunar og verkefnavinnu. Dæmi voru nefnd um að nemendur skiluðu hljóðupptökum í stað texta og jákvætt pótti að nota fjölbreyttari form á verkefnaskilum. Nefnt var að myndbönd yrðu nýtt meira við kennslu og vendikennsla gæti verið kostur en einnig að hagnýta betur rafrænar lausnir í kennslustofunni. Við færslu kennslu á netið varð til „pekking á gerð myndbanda og meiri pekking á framboði viðeigandi myndbanda varð til í kennarastéttinni, sem nýta má í framtíðinni“. Margir höfðu áttað sig á að sá möguleiki að vera með námsefni í formi upptaka sem gerðar eru aðgengilegar á netinu væri góður kostur fyrir nemendur og peir myndu nýta sér í framtíðinni. Sumir höfðu notað efni sem til er á netinu, myndbönd, hlaðvörp og slíkt sem peir sögðust koma til með að nýta í auknum mæli í framtídinni.

Flestir kennarar purftu að læra að nota fjarfundabúnað og voru ánægðir með pað, sáu kosti pess að geta tekið upp t.d. sýnikennslu og útskýringar og kosti pess að geta streymt upptökum. Nefnt var að fjarfundabúnaður myndi nýtast meira til rauntímakennslu í fjar- og dreifnámi í framtíðinni en líka til kennslu með fáum nemendum í einu til að auka tengsl nemenda og kennara. Kennarar töldu að rafræn próf yrðu notuð í ríkari mæli, bæði heimapróf og próf í skóla og einnig munnleg próf í fjarfundabúnaði að einhverju leyti. Sumum fannst að breytingar í námsmati ættu að leiða 
til pess að leiðsagnarmat og símat yrði notað í meira mæli með litlum og tíðum verkefnum par sem námsmatið tæki til fjölbreyttari pátta en vægi lokaprófa yrði minnkað. Nefnt var að notkun tækni væri til pess fallin að auka sjálfstæð vinnubrögð nemenda og skólarnir gætu orðið „djarfari í að taka upp fjölbreyttari kennsluhætti og fyrir nemendur að taka upp breyttar námsvenjur“.

Margir nefndu að nemendur hefðu lært mikið pegar nám og kennsla færðist á netið og bætt pekkingu peirra í notkun stafrænnar tækni, líkt og hjá kennurum. Munnlegar kynningar í gegnum fjarfundabúnað gengu vel og dæmi voru um nemendur sem ekki höfðu treyst sér til að vera með kynningu í skólastofu en létu sig hafa pað að kynna verkefni í fjarfundi. Sumir nemendur virtust finna sig betur með pví að geta unnið á sínum hraða en margir fengu reyndar aðstoð og eftirlit foreldra sem virtist styrkja pá:

Nemandi sem átti að túlka ljóð bað um að fá að syngja pað og túlka pað með tilfinningum og niðurstaðan var að mér barst hljóðvarp par sem móðirin spilaði á gítar og nemandinn söng og petta er besta framlag pessa nemanda par sem hæfileikar hennar komu parna í ljós. Petta var algjör snilld. Meira af pessu - takk :)

Kennarar nefndu að petta hefði verið ágætis tækifæri fyrir marga nemendur til pess að læra að axla ábyrgð á eigin námi. Undir pessum erfiðu kringumstæðum hefðu margir nemendur lært heilmikið varðandi skipulagningu, sjálfstæði og hópavinnu.

\section{Jákvað reynsla af samskiptum við nemendur á netinu}

Í svörum kennara um jákvæða reynslu af fjarkennslunni kom fram að netfundir hefðu gefið tækifæri til að kynnast nemendum á annan hátt, jafnvel persónulegri, og nefnt var að pægilegra gæti verið að vera í beinum spjallsamskiptum við nemendur í stað pess að nota tölvupóst. Kennarar töldu gott að fá tækifæri til að kynnast fleiri möguleikum til samskipta í kennslu og fannst tengslin verða sterkari við að sjá fjarnema í mynd. Kennarar nefndu möguleikann á að vera í beinum tengslum við einstaka nemendur, hafa tíma til að sinna hverjum og einum betur og sáu fyrir sér að nýta pessa reynslu áfram í kennslu.

\section{Námsmat}

Margir kennarar sögðu pað hafa verið mikla áskorun að reyna að finna fjölbreyttar leiðir til námsmats. Margir sögðust hafa minnkað vægi prófa og breytt áherslum í verkefnum með pví að „draga úr námsmati sem byggir á pekkingu sem nemendur geta gúglað og auka námsmat sem byggir á leikni og hæfni“. Nefnt var að erfitt væri að gera próf par sem pví mætti treysta að nemendur leystu verkefni án utanaðkomandi aðstoðar og erfitt væri að útbúa góð heimapróf. „Sáum á svörunum að margir nemendur unnu saman eða fundu svör á netinu." Kennarar nefndu að nemendur hefðu skilað úrlausnum sem voru afrit af verkefnum annarra og erfitt hefði verið að fást við pað. „Nemendur sem ekki voru sterkir skiluðu nánast fullkomnum verkefnum og prófum. Margir skiluðu annarra nemenda verkefnum án pess að reyna að leyna pví.“

\section{Aukinn sveigjanleiki og einstaklingsmiðun i kennslu}

Vakin var athygli á að reynslan af að færa kennsluna á netið hefði sýnt kennurum hvernig hægt væri að bjóða nemendum sem ekki kæmust í skólann vegna veikinda eða annars að sækja kennslustundir í fjarfundabúnaði. Nemendur með félagsfælni eða geðraskanir á borð við punglyndi gátu t.d. nýtt sér petta. Fram kom að kennarar töldu að pað gæti hentað sumum nemendum að nota tölvusamskipti frekar en að sitja inni í kennslustofu og vera hluti af hóp. Tæknilausnir gætu líka gagnast nemendum sem pyrftu einstaklingspjónustu og hægt væri að sinna nemendum með sértæka námsörðugleika utan skóla að einhverju leyti.

Starfsbrautarnemendur sem búa við proskahömlun hafa nokkra sérstöðu en fram kom að sumir nemendur á starfsbrautinni blómstruðu í fjarnáminu og sýndu sjálfstæði og frumkvæði, voru mættir tímanlega á alla netfundi og óskuðu eftir verkefnum ef pau voru ekki komin: 
Við kynntumst peim í raun á nýjan og persónulegri hátt. Einhverfur nemandi sem hafði sýnt töluverða hegðunarerfiðleika í skólanum kom skemmtilega á óvart í fjarkennslunni par sem við náðum miklu betra sambandi við hann í gegnum tölvusamskipti heldur en samskiptum „maður á mann“.

\section{Ábrif takni á störf kennara}

Margir kennarar vonuðust til að fjarfundir yrðu notaðir meira fyrir starfsmannafundi, par sem pað myndi geta sparað ferðakostnað og svo var nefnt að fjarfundir hefðu verið skilvirkari í mörgum tilfellum. Aðrir nefndu að frelsi nemenda og kennara til að sinna vinnu annars staðar gæti aukist. Pannig pyrftu kennslustundir ekki að falla niður vegna ferðalaga eða forfalla kennara par sem peir gætu sinnt kennslu hvar sem peir væru staddir. Kennarar nefndu að jákvætt hefði verið að upplifa að skólasókn pyrfti ekki að vera eins formföst og nú er, „að ekki sé nauðsynlegt að nemendur og kennarar séu saman inni í kennslustofu til pess að nám geti farið fram“. Einn kennari lýsti pessu svo:

Ég er mjög ánægður með reynsluna. Ég hef í gegnum árin nýtt mér tæknina og er mjög hrifinn af pví hvernig félagar mínir og nemendur hafa stigið stórt stökk inn í tæknina. Ég held að fyrirstaðan fyrir innleiðingu nýrrar tækni verði minni innan skólakerfisins.

Nokkrir nefndu aukna samkennd í kennarahópnum. „Ég upplifði ótrúlega samkennd í skólanum, pað voru allir ákveðnir í að láta petta ganga og lögðu mikið á sig til að svo yrði. Hagur nemenda var í forgangi hjá öllum.“

\section{Aukið hlutfall fjarkennslu - skipulag náms og kennslu gati breyst}

Margir kennarar töldu að notkun fjarfundabúnaðar myndi aukast og að kennsla í fjarnámsformi gæti aukist eftir pessa reynslu í samkomubanninu. Nokkuð margir kennarar reifuðu hugmyndir sínar um hvernig reynslan af að færa kennsluna á netið hefði opnað augu peirra fyrir að endurhugsa fyrirkomulag náms með pví að nýta kosti bæði fjarnáms og staðnáms. Til dæmis var nefnt að færa mætti hluta námsins á netið með pví að innleiða vendikennslu, hafa innlagnir kennara á nýju efni á netinu og nýta kennslustundir til að vinna verkefni út frá pví efni sem nemendur hefðu kynnt sér heima. Reynsla kennara af fjarkennslu var talin geta breytt áherslum á mætingar í skóla; hvað og hvernig væri unnið í skólanum og hvað nemendur ynnu heima:

Ég sé fyrir mér að ég gæti kennt hluta af kennslunni minni í fjarkennslu líkt og fyrirlestra og einstaklingsverkefni sem byggjast á lestri gagna en myndi pó vilja halda áfram að hitta nemendur. Sæi pá fyrir mér að hitta nemendur 3/4 af tímanum og 1/4 væru pau heima að læra. T.d. væri hægt að helga einn dag í viku eða tvo eftirmiðdaga eða eitthvað svoleiðis fjarkennslu á meðan rest væri staðnám.

Einnig mætti hugsa sér að hægt sé að leyfa nemendum að mæta í tíma í gegnum fjarfundabúnað pegar veður eða annað hamla pví að pau geti mætt í skólann og að kennarar setji námsefni og verkefni á netið og nemendur geti sótt pað pangað ef peir missa af tíma.

Kennarar sáu fyrir sér að aukin nýting stafrænnar tækni meðfram hefðbundinni kennslu gæti boðið upp á meiri sveigjanleika við skipulag náms og uppsetningu stundaskrár pannig að fækka mætti föstum tímum í stundatöflu nemenda og fjölga opnum tímum par sem engin mætingarskylda væri. „Við erum alltof bundin við hefðbundna kennsluhætti, stundatöflur og stofuskipulag sem heftir bæði kennara og nemendur."

Sú skoðun kom fram að fjarnám ætti að vera valmöguleiki í öllum áföngum í framtíðinni og að hugsanlega væri hægt að sampætta dagskóla og fjarnám með einhverjum hætti. Einn kennari hafði eftirfarandi framtíðarsýn:

Ég tel að framtíðarsýnin liggi í augum uppi og við munum ekki hafa pörff fyrir skólahúsnæði í sama formi og hingað til. Pað er ekki lengur pörf á skólastofum. Ég tel miklar líkur á pví að framhaldsskólar muni leggjast af í pví formi sem peir hafa verið og eru 2020. 
Pá var nefnt að mikilvægt væri í ljósi reynslunnar að móta stefnu innan hvers skóla um hvaða tækni væri notuð og kenna kennurum og nemendum vel á hana pannig að allir væru undirbúnir fyrir tímabil sem petta og hægt væri að færa staðnám yfir í fjarnám með stuttum fyrirvara.

\section{Mun ekki breyta kennsluháttum til frambúðar}

Í hópi pátttakenda rannsóknarinnar heyrðust líka raddir sem sáu alls ekki fyrir sér að pessi tímabundna reynsla myndi breyta kennsluháttum til frambúðar. Færslan á netið hefði verið „illa undirbúnar neyðarráðstafanir [sem ættu] ekki að hafa áhrif á starfshætti framhaldsskóla til frambúðar“. Nefnt var að reynslan hefði styrkt skoðun kennara á að mikilvægustu samskiptin færu fram inni í kennslustofu og að fjarnám væri ekki nemendavænt nám, jafnvel að „fjarkennsla [væri] ekki kennsla, heldur afgreiðsla“:

Ég held að pessi reynsla sýni okkur hvað mannleg samskipti í kennslu eru mikilvæg og að tölvur og tækni geti ALDREI komið í stað persónulegra samskipta nemenda við kennara. pað er pó hægt að vera pakklátur fyrir tæknina pví án hennar hefðum við komið enn verr út úr pessu ástandi.

Fram kom að sumir kennarar hefðu sannfærst um gildi staðnáms fyrir nemendurá framhaldsskólaaldri:

Ég hef sannfærst enn frekar um kosti staðnáms umfram fjarnám fyrir langflesta nemendur a.m.k. á framhaldsskólastigi.

Einn kennari taldi að pað hvort breytingar yrðu til frambúðar væri háð kjaramálum og vinnuálagi og hvernig vinnuveitendur vildu greiða fyrir slíka vinnu fremur en kunnáttu kennara. Annar hafði „áhyggjur af pví að skólastjórnendur [sæju] sér sóknarfæri í að bjóða upp á netkennslu án pess að skoða nógu vel kosti og galla“. Sá priðji sagði:

Ég upplifi petta tímabil EKKI sem einhvers konar tímamótatímabil par sem kennarar hafi uppgötvað galdratækni og fjarnám.

Ofangreind dæmi sýna að efasemndarraddir voru uppi meðal kennara varðandi breytingar til framtíðar.

\section{Samantekt og umræður}

Að breyta kennsluháttum fyrirvaralaust úr kennslu í skóla yfir í fjarnám á netinu var auðvitað mikil áskorun og gerði pær kröfur til kennara að aðlaga námsefni og verkefni að námi og kennslu á netinu án pess að fá tíma til að undirbúa pað.

Hér hafa verið teknar saman helstu niðurstöður um hvernig skólar tókust á við að færa nám og kennslu í fjarnám pegar skólunum var lokað. Lýst var peim tæknilegu og kennslufræðilegu áskorunum sem pað hafði í för með sér og að hvaða marki kennarar töldu að reynslan af breytingunum kæmi til með að hafa áhrif á próun kennsluhátta til framtíðar.

\section{Meirihluti skóla vel settur varðandi búnað, mannauð og aðgengi nemenda að tækni}

Langflestir peirra stjórnenda sem svöruðu spurningu um stafrænan búnað skólanna töldu sína skóla mjög vel eða frekar vel búna stafrænum verkfærum. Mikill minnihluti taldi skólana frekar illa búna eða hvorki vel né illa. Pá taldi meirihluti bæði kennara (74\%) og stjórnenda (88\%) að aðgengi nemenda að tækni hefði dugað mjög eða frekar vel til samskipta og fjarnáms í samkomubanninu. Nær allir stjórnendur (94\%) töldu að starfsfólk hefði verið mjög vel (40\%) eða frekar vel (54\%) búið undir aukin tölvusamskipti og fjarkennslu. Athyglisvert er að tæpur helmingur kennara sagðist hafa 
reynslu af fjarkennslu áður en skólunum var lokað. Petta parf ekki að koma á óvart í ljósi pess að í yfir 20 ár hefur verið unnt að stunda nám í framhaldsskólum á Íslandi i fjarnámi og á undanförnum árum hefur um helmingur framhaldsskóla boðið upp á fjarnám af einhverju tagi (Hagstofa Íslands, 2020). Petta á við um flesta skóla á landsbyggðinni en sumir peirra eru litlir pannig að prátt fyrir petta er meirihluti nemenda og kennara í skólum sem ekki hafa boðið fjarnám. Marktækur munur var á svörum stjórnenda eftir reynslu af fjarkennslu í skólum peirra. Pannig taldi mikill meirihluti stjórnenda (71\%) úr peim 16 skólum par sem yfir 60\% kennara var með reynslu af fjarkennslu að starfslið skóla hefði verið mjög vel undirbúið fyrir að sinna nemendum í fjarnámi á meðan innan við helmingur stjórnenda peirra skóla sem höfðu litla eða enga reynslu af fjarnámi taldi svo vera.

\section{Aukin færni kennara í notkun stafrænnar tækni og breytingar til framtíðar}

Eins og fram hefur komið hefur orðið mikil próun á sviði fjarnáms í framhaldsskólum hér á landi undanfarna áratugi (sjá t.d. Sólveig Jakobsdóttir og Puríður Jóhannsdóttir, 2018). Greining á svörum kennara við opnum spurningum leiddi í ljós að helstu áskoranir snerust um vandamál við að halda sambandi við nemendur og passa að peir gæfust ekki upp. Næstflest svör snerust um aukið álag á kennara og vinnuaðstæður heima fyrir. Sömuleiðis var mikil áskorun að laga fjölbreytta kennsluhætti sem kennarar höfðu próað í kennslustofunni að fjarkennslu. Sumir nefndu að tilhneiging hefði verið til að kennslan færðist í hefðbundið form par sem kennari væri í hlutverki miðlara en nemendur óvirkir hlustendur.

Flestum kennurum fannst að pörfin á að læra á mörg ný forrit hefði verið jákvæð reynsla. Aukin hæfni á pessu sviði væri líkleg til að hafa áhrif á kennsluhætti peirra til frambúðar og myndi eiga pátt í að gera pá fjölbreyttari. Ljóst er að hæfni kennara í upplýsingatækni gegndi lykilhlutverki pegar kennsla purfti að færast í fjarnám vegna farsóttarinnar, og pað er í samræmi við alpjóðlegar rannsóknir (König o.fl., 2020). Svör kennara sýna að peir veltu fyrir sér kostum og göllum stafrænnar tækni til náms og kennslu út frá kennslufræðilegum möguleikum. Petta bendir til að líkt og í rannsókn Teräs og félaga (2020) hafi reynslan af að færa kennsluna í fjarnám styrkt fagmennsku kennara.

Reynslan af kennslu á netinu opnaði augu kennara fyrir tækifærum til að koma betur til móts við sérstakar parfir einstakra nemenda eða hópa nemenda, með nýtingu tækni. Sú áhersla hefur verið mikið til umræðu varðandi próun skólastarfs síðustu ár og áratugi. Sumir kennarar töldu líklegt að skólar myndu í auknum mæli bjóða upp á blandað nám, p.e. nýta bæði fjarnám og staðnám sem gæti orðið til pess að auka sveigjanleika í skólastarfi. Petta er í samræmi við reynslu af starfi Fjarmenntaskólans par sem fjarnám hefur opnað leið til að auka sveigjanleika í námsframboði í framhaldsskólum á landsbyggðinni (Sólveig Jakokbsdóttir og Puríður Jóhannsdóttir, 2018). Einnig kom pó fram að reynsla framhaldsskólakennara af að færa kennsluna í fjarnám var misjöfn og par með sýn peirra á hvernig pessi reynsla væri líkleg til að hafa áhrif á framtíðina. Sumir kennarar sáu enga breytingu fyrir sér sem gæti bent til að í framhaldsskólum verði togstreita á milli pess að halda í hefðbundna starfshætti og pess að próa nýja og framsækna starfshætti á grunni reynslu af fjarkennslu á tímum farsóttar.

Reynslan af pessari óundirbúnu færslu kennslu í framhaldsskólum yfir í fjarnám sýnir að tæknifærni kennara og kennslufræðileg pekking gegndi lykilhlutverki í hvernig til tókst. Til að tæknin nýtist til náms og kennslu í framtîðinni er brýnt verkefni að sjá til pess að kennarar búi yfir pessari hæfni. 


\section{Distance education and digital technologies in upper secondary schools during a pandemic: Views of teachers and school administrators}

Distance learning at upper secondary school level (grades 11 to 13) in Iceland has been developing since the early 90 s and online learning has become an important part of how many schools organize their programmes with different blended learning models. Rural schools have used the flexibility of online access to open up possibilities for their students to select courses available in the other schools. Also they have organized vocational programmes as a blend of face-to-face and online modules, sometimes in collaboration with specialized schools in Reykjavík for enabling people in rural districts to access more diverse education. In the school-year 2019-2020 distance students were enrolled in about $50 \%$ of Icelandic upper secondary schools; thus, many schools have considerable experience in planning and implementing distance learning. However, the majority of upper secondary students are enrolled in schools that have relied mostly on faceto-face teaching and learning. During the 2020 spring semester school buildings were closed due to the COVID-19 pandemic, necessitating all teaching to be moved online. Surveys were sent out during the 2020 spring semester by the Educational Research Institute (ERI) at the University of Iceland School of Education to start monitoring the effects of the COVID-19 situation on students and schools at the preschool, primary and secondary level in Iceland. RANNUM - Centre for Educational Research on ICT and Media contributed survey questions relating to the use of digital technologies and online learning. The focus was on how the schools were prepared and able to cope with increased distance and online learning, changes in the use of digital technology and how pedagogical and technical support for teachers was provided in these altered circumstances. Additional focus was placed on how the experience of distance learning could affect the development of teaching methods and the future organization of the curriculum.

In this paper we outline the results from the survey answered by 823 teachers and school administrators from 35 upper secondary schools. Most administrators (94\%) thought their schools were very well or rather well equipped, regarding technology and digital tools and felt their teachers were well prepared. Many teachers (41\%) reported previous experience of distance teaching and about half of them believed experience and exposure to distance learning and teaching had helped them during the period. Most school administrators $(88 \%)$ thought that students' access to technology had been sufficient and served them very well, or at least rather well, for online communication and distance learning. Significantly fewer teachers, (74\%), felt that students' access to technology had served them very well or rather well Answers to open-ended questions revealed teachers' views regarding the main challenges they faced. Many felt it was difficult to stay in contact with all of their students and had tried to ensure that they did not give up on their studies. There were reports of additional stress as teachers had to work from home often under demanding working conditions. Also, some felt it was hard to apply a variety of teaching methods and thought there was a tendency for the online teaching to be more traditional and use a one-way transmission from teacher to students. On the other hand, the experience opened the eyes of many teachers to new opportunities, including better meeting students' needs by using a more individualised approach instead of traditional methods. Some teachers anticipated that in the future schools would increasingly employ blended learning methods which could provide increased flexibility in education.

The experience of this unprepared transfer of teaching in upper secondary schools to 
distance learning shows that teachers' technical skills and pedagogical knowledge played a key role in the outcome. The importance of technology for learning and teaching in the future makes it an urgent task to ensure that teachers have these competencies or can acquire them through access to relevant professional development.

Key words: COVID-19, distance learning, teachers' pedagogical and technological knowledge, digital technology, upper secondary schools

\section{Um höfunda}

Puríður Jóna Jóhannsdóttir (thuridur@hi.is) er prófessor í menntunarfræðum við Menntavísindasvið Háskóla Íslands og námsbrautarformaður í kennslufræði framhaldsskóla. Hún lauk BA-prófi í íslensku og pjóðfélagsfræði frá HÍ árið 1978, M.Ed.-prófi í menntunarfræði frá Kennaraháskóla Îslands 2001 og doktorsprófi í uppeldis- og menntunarfræði frá HÍ 2010. Rannsóknir hennar hafa snúist um fjarnám í kennaranámi og á framhaldsskólastigi, notkun upplýsingatækni í námi og kennslu á öllum skólastigum, próun kennsluhátta í háskóla og framhaldsskóla og námskrárpróun. ORCID ID: https://orcid.org/0000-0003-2694-1864

Sólveig Jakobsdóttir (soljak@hi.is) er prófessor við Menntavísindasvið Háskóla Íslands. Hún lauk M.Ed.-prófi 1989 frá University of Minnesota og doktorsprófi frá sama skóla 1996 í kennslufræði með áherslu á tölvunotkun í menntun. Sólveig hóf störf við Kennaraháskóla Íslands 1997 og hefur stýrt Rannsóknarstofu í upplýsingatækni og miðlun frá stofnun stofunnar 2008. Rannsóknir hennar og kennsla hafa snúið að upplýsingatækni í námi og kennslu og fjar- og netnámi. ORCID ID: https://orcid. org/0000-0002-4205-0888.

\section{About the authors}

Thurídur Jóna Jóhannsdóttir (thuridur@hi.is) is a professor in educational studies at the School of Education, University of Iceland and chair in pedagogy for upper secondary teachers. She holds a BA degree in Icelandic and sociology from University of Iceland, completed an M.Ed. degree in pedagogy in 2001 at the Iceland University of Education, and a Ph.D. in educational studies in 2010 at the University of Iceland. Her research includes online learning, teacher education, ICT in education, development of teaching and learning in higher education and upper secondary education, and curriculum development. ORCID ID: https://orcid.org/0000-0003-2694-1864

Sólveig Jakobsdóttir (soljak@hi.is) is a professor at University of Iceland School of Education. She completed an M.Ed. degree in instructional systems and technology in 1989 from University of Minnesota and a doctoral degree from the same institution in 1996, focusing on school computer use. Sólveig started work at Iceland University of Education in 1997 and has led RANNUM - Centre for Educational Research on ICT and Media from its foundation in 2008. Her research and teaching has been on ICT in education, and online and distance teaching and learning. ORCID ID: https://orcid. org/0000-0002-4205-0888. 


\section{Heimildir}

Flick, U. (2006). An introduction to qualitative research. London: Sage.

Hagstofa Íslands. (2020). Nemendur ofan grunnskóla eftir skólastigi, skólum, lögheimili, kennsluformi og kyni 1997-2019. Sótt af https://www.hagstofa.is

König, J., Jäger-Biela, D. J. og Glutsch, N. (2020). Adapting to online teaching during COVID-19 school closure: Teacher education and teacher competence effects among early career teachers in Germany. European Journal of Teacher Education, 43(4), 608-622. doi:10.1080/02619768.2020.18 09650

Sólveig Jakobsdóttir og Puriðður Jóhannsdóttir. (2010). Úttekt á fjarkennslu i framhaldsskólum (unnið fyrir mennta- og menningarmálaráðuneytið). Sótt af http://brunnur.stjr.is/mrn/utgafuskra/utgafa. nsf/RSSPage.xsp?documentId=17FA42CC5B0EA1D6002577960047E5BB\&actioN=openDocume nt

Sólveig Jakobsdóttir og Puriðður Jóhannsdóttir. (2018). The development of K-12 online and blended learning in Iceland. Î K. Kennedy og R. Ferdig (ritstjórar), Handbook of K-12 online and blended learning research (2. útgáfa, bls. 649-664). Sótt af https://press.etc.cmu.edu/index.php/product/ handbook-of-research-on-k-12-and-blending-learning-second-edition/

Teräs, M., Teräs, H., Arinto, P., Brunton, J., Daryono, D. og Subramaniam, T. (2020, 30. júní). COVID-19 and the push to online learning: Reflections from 5 countries. Digital Culture and Education. Sótt af https://www.digitalcultureandeducation.com/reflections-on-covid19/reflectionsfrom-5-countries\#

Puríður Jóhannsdóttir. (2007). Spjallfrelsi. Kenningum Bernsteins beitt í rannsókn á fjarnámi. Í Gunnar Pór Jóhannesson (ritstjóri), Rannsóknir i félagsvisindum VIII (bls. 771-781). Reykjavík: Félagsvísindastofnun Háskóla Íslands.

Puríður Jóhannsdóttir. (2017). Creating a school that matters: Networking for school-community development. Journal of Curriculum Studies, 50(3), 297-314. doi:10.1080/00220272.2017.1337812

Puríður Jóna Jóhannsdóttir og Sólveig Jakobsdóttir. (2020).

Fjarkennsla og stafræn tækni í framhaldsskólum á tímum farsóttar vorið 2020: Sjónarhóll kennara og stjórnenda

Netla - Veftímarit um uppeldi og menntun: Sérrit 2020 - Menntakerfi og heimili á tímum COVID-19

Sótt af http://netla.hi.is/serrit/2020/menntakerfi_heimili_covid19/10.pdf

DOI: https://doi.org/10.24270/serritnetla.2020.26 